\title{
New species of Elateridae (Coleoptera) from Madre de Dios, Peru, with new taxonomic changes and distribution records
}

\section{Especies nuevas de Elateridae (Coleoptera) de Madre de Dios, Perú, con nuevos cambios tax- onómicos y registros de distribución}

\section{Paul J. Johnson ${ }^{1}$, Hannah K. Boyd ${ }^{2}$ and Caroline S. Chaboo ${ }^{3}$}

\author{
1 Insect Biodiversity Lab, Box 2207A, South Dakota State University, Brookings, SD 57007. U.S.A. \\ 2 Snow Entomological Museum, 1501 Crestline Ave, Suite 140, University of Kansas, Lawrence, KS 66045, U.S.A. \\ 3 Systematics Research Collections, W436 Nebraska Hall, University of Nebraska, Lincoln, NE, 68588, U.S.A. \\ E-mail Paul Johnson: paul.johnson@sdstate.edu \\ E-mail Hannah Boyd: hamkboyd@yahoo.com \\ E-mail Caroline Chaboo: insectrescons@gmail.com
}

\begin{abstract}
The Elateridae fauna of Peru is updated with species new to science, new country records and new taxonomic combinations from the Madre de Dios region. Ten species representing eight genera are described as new: Conoderus wachiperi new species (Agrypninae, Oophorini) Cosmesus aca new species (Elaterinae, Pomachilini), Dipropus amarakaeri new species and Dipropus losamigos new species (Elaterinae, Ampedini, Dicrepidiina), Esthesopus machiguenga new species (Cardiophorinae), Glyphonyx peruanus new species (Elaterinae, Adrastini), Lissomus carmen new species (Lissominae), Paradonus kosnipata new species (Negastriinae), and Pomachilius qusqu new species and Pomachilius wayqecha new species (Elaterinae, Pomachilini). Aeolus platynotus Candèze is changed to Conoderus platynotus (Candèze) new combination and Aeolus ticuna Johnson is changed to Conoderus ticuna (Johnson) new combination (Agrypninae, Oophorini); and Crigmus brunnipilis (Candèze) is changed to Probothrium brunnipilis (Candèze) new combination (Elaterinae, Elaterini). Twenty-seven (27) species, the genera Glyphonyx Candèze and Paradonus Stibick, the tribe Adrastini, and the subfamily Negastriinae are added to the Peru faunal list. There are now 201 species representing 48 genera and 9 subfamilies recorded from Peru.
\end{abstract}

Key words. Taxonomy; biodiversity; click beetle; Andes; Amazonia.

Publicación registrada en Zoobank/ZooBank article registered: LSIDurn:Isid:zoobank.org:pub:667E8E04-35B4-42D3-9E80-EE0D365BED7A Acto nomenclatural/nomenclatural act:

1. Conoderus wachiperi Johnson in Johnson, Boyd \& Chaboo, 2018 LSIDurn:Isid:zoobank.org:act:10E1686E-6CCB-4BC0-890B-E4F4AE1AB7AA 2. Cosmesus aca Johnson in Johnson, Boyd \& Chaboo, 2018 LSIDurn:Isid:zoobank.org:act:ODEA3618-48AB-4822-B8A9-C1AF24502386 3. Dipropus amarakaeri Johnson in Johnson, Boyd \& Chaboo, 2018 LSIDurn:Isid:zoobank.org:act:4DD05342-3C00-441B-860B-543CD3EC607F 4. Dipropus losamigos Johnson in Johnson, Boyd \& Chaboo, 2018 LSIDurn:Isid:zoobank.org:act:7A9F602A-94D6-4608-843B-D69B1ED30405
5. Esthesopus machiguenga Johnson in Johnson, Boyd \& Chaboo, 2018 LSIDurn:Isid:zoobank.org:act:845B8D8F-3414-4BB6-88BB-1060F00312B0 6. Glyphonyx kosnipata Johnson in Johnson, Boyd \& Chaboo, 2018 LSIDurn:Isid:zoobank.org:act:19BD725A-47EA-452F-9B26-F439AF79CD5E 7. Lissomus carmen Johnson in Johnson, Boyd \& Chaboo, 2018 LSIDurn:Isid:zoobank.org:act:59ADC759-46CE-42D5-AEAA-C2CD74C9C2F8 8. Paradonus esaejas Johnson in Johnson, Boyd \& Chaboo, 2018 LSIDurn:Isid:zoobank.org:act:8420EEDC-B324-4799-81CE-0EC7E84E5354 9. Pomachilius qusqu Johnson in Johnson, Boyd \& Chaboo, 2018 LSIDurn:Isid:zoobank.org:act:0F161BB8-9C1F-41E2-AB14-7DEC411F0BEB 10. Pomachilius wayqecha Johnson in Johnson, Boyd \& Chaboo, 2018 LSIDurn:Isid:zoobank.org:act:91518490-03E8-4503-8876-189277D89F7F
Citation:

Johnson P.J, H.K. Boyd \& C.S. Chaboo. 2018. New species of Elateridae (Coleoptera) from Madre de Dios, Peru, with new taxonomic changes and distribution records. Revista peruana de biología 25(2): 075 - 090 (Mayo 2018). doi: http://dx.doi.org/10.15381/rpb.v25i2.14685

Funding: National Science Foundation grant EPSCoR 66928 (to CSC) and KU Undergraduate Research Award (to HKB).

$\begin{array}{ll}\text { Presentado: } & 08 / 02 / 2018 \\ \text { Aceptado: } & 10 / 03 / 2018\end{array}$

Publicado online: 30/05/2018

\begin{abstract}
Author Contributions: Conceptualization: FGPYA. Data curation: FGP FM CDG YA. Formal analysis: FM. Funding acquisition: YA. Investigation: FGP CDG. Project administration: FGP. Resources: FGP FM. Supervision: FGP. Visualization: FGP FM. Writing - original draft: FGP FM CDG. Writing - review \& editing: FGP FM YA

The authors have declared that no competing interests exist.
\end{abstract}

Scientific Collecting Permits: Servisio Nacional Forestal y de Fauna Silvestre (SERFOR) del Ministerio de Agricultura y Riego - permisos de recolección No. 084-2012-AG-DGFFS-DGEFFS - 0148-2013-AGDGFFS-DGEFFS 


\title{
Resumen
}

\begin{abstract}
La fauna Elateridae del Perú se actualiza con especies nuevas para la ciencia, nuevos registros de países y nuevas combinaciones taxonómicas de la región de Madre de Dios. Diez especies que representan ocho géneros se describen como nuevas: Conoderus wachiperi nueva especie, Cosmesus aca nueva especie, Dipropus amarakaeri nueva especies, Dipropus losamigos, nueva especie, Esthesopus machiguenga nueva especie, Glyphonyx peruanus nueva especie, Lissomus carmen nueva especie, Paradonus kosnipata nueva especie, Pomachilius qusqu nueva especie, Pomachilius wayqecha nueva especie. Aeolus ticuna Johnson se cambia a Conoderus ticuna (Johnson) nueva combinación, Aeolus platynotus Candèze se cambia a Conoderus platynotus (Candèze) nueva combinación, y Crigmus brunnipilis (Candèze) se cambia a Probothrium brunnipilis (Candèze). Veintisiete (27) especies, los géneros Glyphonyx Candèze y Paradonus Stibick, la tribu Adrastini y la subfamilia Negastriinae se agregan a la lista de fauna de Perú. Ahora hay 201 especies que representan 48 géneros y 9 subfamilias se registran en el Perú.
\end{abstract}

Palabras claves. Taxonomia; biodiversidad; elateridos; Andes; Amazonía.

\section{Introduction}

The click beetle family Elateridae (Coleoptera) remains inadequately studied in Peru, with few modern taxonomic or faunal studies, but the paucity of attention is changing. A recent summary by Johnson and Chaboo (2015) listed 174 species classified in 46 genera and 8 subfamilies. Subsequently, Johnson (2017) described a new species of Dodecacius Schwarz, and additional new taxa and records are presented below to update the working checklist for Peru to 201 species and 48 genera in 9 subfamilies.

The Elateridae were included in the sampling results for Coleoptera of the Andean eastern slopes, foothills and adjacent lowlands in southeastern Peru in the Beetles of Peru project (Chaboo 2015, Chaboo and Catenazzi 2015). Most of the specimens and those reported below were collected at the Centro de Investigación y Capacitación Rio Los Amigos (CICRA), or Los Amigos Biological Station, along the Rio Madre de Dios, approximately 100 air kilometers west of Puerto Maldonado. The biological station is located adjacent to the Los Amigos Conservation Concession and the Manu-Tambopata Corridor between Manu National Park and Tambopata National Reserve. The area is an example of lowland Amazon rainforest with low topographic relief and high water tables near to the eastern foothills of the Andes. The new Interoceanic Highway traverses the region from Brazil to Puerto Maldonado, then to Cusco and three Pacific ports, and enables increased incursions and alterations to forest and riverine habitats. Some additional specimens were collected in the Andean foothills (ca. $500 \mathrm{~m}$ ) in premontane rainforest at the Villa Carmen Biological Station within the Manu Biosphere Reserve, and upper montane (ca. $2800 \mathrm{~m}$ ) cloud forest at the Wayqecha Cloud Forest Biological Station overlooking the Kosñipata Valley. The specimens presented herein were collected by all basic insect sampling methods, especially beating, gleaning, UV light trap, colored pan traps, and Malaise and other flight interception traps.

Peru is generally considered an extraordinary country for biodiversity because of its diverse environmental settings set entirely within tropical latitudes, including coastal desert, alpine Andes, and Amazon basin and transitions between these biomes (e.g., Kricher 1997; Lamas 1997; Mittermeier et al. 1997; Erwin and Geraci 2009; Larsen et al. 2011). The Andean-Amazonian transition slopes are recognized as a global biodiversity hotspot (Myers et al. 2000) because of its unique combination of climate, geology, and complex vegetation (Foottit and Adler 2009). The region is threatened by commercial exploitation and encroachment, including gold mining, logging, road network construction, and a proposed dam construction (Laurance 1998, Laurance et al. 2011).
Foottit and Adler (2009) discussed two challenges that limit the application of insect-based biomonitoring strategies in South America. First, there is a very large number of species to be identified from survey data, which has accumulated in part to a lack of taxonomic resolution. Second, reaching a good degree of taxonomic resolution for insects is critical for understanding ecological patterns and identifying/detecting disturbances in changes of any insect community. Aguirre and Johnson (2014) ranked Peru in sixth place for documented click beetle diversity among all South American countries. Sampling of these beetles and their relatives to date has largely been serendipitous collecting or relatively small structured projects by individual workers. In contrast, systematic sampling can be reasonably expected to add tremendously to documenting their diversity as most of the undescribed taxa that are known are small-sized, regionally endemic, generally overlooked by non-specialists, or are members of taxonomically neglected groups. Examples of each of these factors were treated by Johnson and Chaboo $(2015,2016)$, and in this and pending reports.

Here, we add to the biodiversity knowledge of Peru and address the two main biodiversity challenges given by Foottit and Adler (2009) by reporting on discoveries with the taxonomic treatment of species new to science and new occurrence records in Peru for click beetle species. Ten (10) species new to science are described, three species receive genus transfers, and an additional 14 species are reported from Peru for the first time.

\section{Materials and methods}

Data for this study was assembled from field collections in 2010-2014 as part of the Beetles of Peru research project as detailed by Chaboo (2015). Specimen collections in that project uses various traps: Malaise (mainly terrestrial), flight interception, colored pan, and ultra-violet light traps; beating (sometimes with fumigation) is also used on lower vegetation. Most of the click beetles were recovered from Malaise and other flight interception traps. Additional specimens came primarily from the Snow Entomological Museum Collection (SEMC), University of Kansas, Lawrence, U.S.A., and the Universidad Nacional Mayor de San Marcos, Museo de Historia Natural (MUSM), Lima, Peru. Pertinent primary types of species were examined at the Natural History Museum, London (BMNH), U.K., the Museum für Naturkunde (MFNB), Berlin and the Senckenberg Deutsches Entomologisches Institut (SDEI), Müncheberg, Germany.

The new species were recognized by comparison with specimens of other known species within these genera and by published historical taxonomic literature. Species concepts are 
morphology-based. Descriptive measurements of morphological structures follow Johnson $(2015,2016)$, and were made with an ocular micrometer at 0.1 and $0.01 \mathrm{~mm}$ increments between 10-50 magnifications. Morphological terms and concepts generally follow Calder (1996) and Lawrence et al. (2010). Integument color terms are based on Nichols and Schuh (1989). Body length was measured from the anterior margin of the frons to the elytra apices, and width is measured across the elytral humeri. Antennomere $2-11$ length ratios are given in those taxa where the values are useful, and were measured along the lateral midline from antennomere base to apex, and values are rounded to one decimal place. The string of values is usually given only for antennomeres $2-4$ or $2-5$ and 11 , when antennomeres 5 or 6-10 are the same. The entire string of values is presented for those species that have antennomeres $3-5$ and $6-10$ of differing lengths. Pronotal length is along the midline from anterior margin to the antescutellar emargination, and width is at widest point at midlength or base of the hind angles. Metatarsomere lengths were measured along the dorsal midline, from basal to distal margins, values are rounded to two decimal places, and given as a ratio string.

Label data is presented as given on the specimens. Information from separate labels is separated a slash ( / ) bracketed by single spaces. Interpolated information is given within squared brackets as needed for clarity or supplementation.

Species presented represent a variety of family-group and genus taxa, thus the descriptions of each new taxon are not necessarily consistent in characters given between the taxa presented. The descriptions are designed to use characters of value within the genus or appropriate set of related next higher taxa.

Collection abbreviations follow Evenhuis (2018). The field sampling and lab research were conducted under permits numbered 506-2011-AG-DGFFS-DGEFFS and 0159-2010-AGDGFFS-DGEFFS issued by the Peru Ministry of Agriculture to C.S. Chaboo. Holotypes designated herein will be returned to the MUSM. Paratypes and non-types are deposited in MUSM, SEMC, with a few examples retained in PJJC. Since specimens have unique barcodes specimen numbers by repository are not added with collection abbreviation.

\section{Systematics}

FAMILY ELATERIDAE LEACH, 1815

\section{Descriptions of New Species}

\section{Conoderus wachiperi Johnson, new species}

(Figs. 1, 11)

Diagnosis: Characters of Conoderus Eschscholtz as defined by Candèze (1859), Schwarz (1906b) and Johnson (1995). This new species is small $(5.0 \mathrm{~mm}$ length) for the species of the region of occurrence, has variable infuscate maculations on the pronotum and elytra, the elytral apices emarginate and spinulate, and aedeagal morphology (Fig. 11).

Description. Body (Fig. 1) length 5.0 mm, width 1.4-1.5 $\mathrm{mm}$; integument brown-yellow (testaceous to brunneotestaceous), with infuscate head; pronotum with variable infuscate markings: median vitta, transverse anterior margin, lateral maculae posterior of midlength to mostly infuscate with hind angles testaceous; elytra variably colored brunneous to light infuscate entirely or with subapical transverse band between testaceous midlength and subapical streaks or maculae.

Head with frontal carina shallowly arcuate to broadly subtruncate. Antenna moderate in length, antennomere 11 reaching pronotal hind angle apex; antennomere 2-4 and 11 length ratio 1.0:1.0:1.5, 2.3.

Pronotum length $0.97 \mathrm{X}$ width, widest at posterior third, slightly sinuate before hind angles. Dorsal carina of hind angle sharp, slightly divergent from lateral margin, reaching onethird distance to anterior margin. Metatarsomere length ratio 1.00:0.58:0.42:0.17:0.58; tarsomere 4 membranous anteroventral lobe broad, $0.5 \mathrm{X}$ length of tarsomere 5; claw simple, shallowly arcuate.

Elytral length $1.5 \mathrm{X}$ width. Striae moderately-coarsely punctured, punctures distinct. Intervals shallowly convex. Apices each subtruncate to shallowly emarginated, with sutural angle and interval 3 spined.

Aedeagus (Fig. 11) with median lobe constricted at midlength, apically spatulate. Paramere broad basally, rapidly narrowing, subparallel through most of length to apical membrane; apex with 2 long, hair-like setae and 4 short, bristle-like subapical spiniform setae along lateral margin; ventrally separate, articulate.

Type material. Holotype, male; PERU: Cusco Dept., Villa Carmen field station, 500 meters east of cafeteria, $12.89459^{\circ} \mathrm{S}$, $71.39928^{\circ} \mathrm{W}, 504 \mathrm{~m}, 31 . v .2011$, D.J. Bennett, beating branches \& fumigant, PER-11-DJB-049 / SEMC0984152 (MUSM).

Paratypes labeled as holotype: SEMC0984184 (MUSM), SEMC0984177 (SEMC).

Etymology. The species epithet "wachiperi" is treated as a noun in apposition and is in reference to the Wachiperi indigenous community in the area of Manu National Park where the type locality is located.

Notes. Conoderus Eschscholtz is comprised of approximately 420 species globally, with the greatest numbers of described species in the Americas (ca. 200 spp.) and Australia (ca. 130 spp.). The genus is highly variable and was historically divided into various genus-level taxa especially Monocrepidius Eschscholtz, and undefined infrageneric groups. Conoderus wachiperi is best associated with species in the varians-group of species that includes a number of species including C. exclamationis (Candèze), C. galapagoensis Van Dyke, C. peruanus (Schwarz), and C. varians (Steinheil).

\section{Cosmesus aca Johnson, new species}

(Figs. 2, 12)

Diagnosis: Characters of Cosmesus Candèze (1863) and Schwarz (1907). This small species has a proportionately short pronotum relative to the elytra, and a distinctive dorsal maculation, filiform tarsi, truncate and denticulate elytral apices, and antennae reaching two antennomeres beyond apices of pronotal hind angles.

Description. Body (Fig. 2) length $4.1 \mathrm{~mm}$, width $1.3 \mathrm{~mm}$; integument red-yellow (rufotestaceous), with infuscate head 
variably patterned; pronotum with oval median vitta separate from anterior margin, reaching posterior margin, lateral maculae at midlength; elytra infuscate, intervals 2-4 diffusely pale; venter infuscate on meso- and metathoraces, abdominal ventrites. Antennae and legs rufotestaceous.

Head with frontal carina evenly arcuate, forming a polished bead. Antennomere 10 exceeding pronotal hind angle apex; antennomeres 2-4 and 11 length ratio 1.0:1.0:1.4, 2.3 .

Pronotum length $0.82 \mathrm{X}$ width (1.21X wider than long), widest at posterior third, slightly sinuate before hind angles. Dorsal carina of hind angle fine, divergent from lateral margin, reaching $0.5 \mathrm{X}$ distance to anterior margin. Metatarsomere length ratio 1.00:0.45:0.45:0.27:0.55; tarsi filiform; claw simple, arcuate.

Elytral length $2.53 \mathrm{X}$ width. Striae finely engraved and punctured. Intervals flat, sparsely scabrous; apices broadly emarginate, with short spines at sutural angle and interval 3 .

Aedeagus (Fig. 12) with median lobe shallowly constricted at midlength giving a spatulate dorsal habitus; paramere deeply sinuate before subsagittate apex; ventrally separate, articulate.

Type material. Holotype male; PERU: Cusco Dept., Villa Carmen field station, 500 meters east of cafeteria, $12.89459^{\circ} \mathrm{S}$, $71.39928^{\circ} \mathrm{W}, 504 \mathrm{~m}, 31 . v .2011$, D.J. Bennett, beating branches \& fumigant, PER-11-DJB0049 / SEMC0984178 (MUSM).

Paratype labeled same as holotype: SEMC0984139 (MUSM).

Etymology. The species epithet " $a c a$ " is treated as a noun in apposition and is derived from the abbreviation for the Amazon Conservation Association.

Notes. Cosmesus comprises nearly 80 described species endemic to South America and the southern Lesser Antilles, but is in need of considerable taxonomic work. Cosmesus aca is the eighth species of the genus reported from Peru (Johnson and Chaboo 2015).

\section{Dipropus amarakaeri Johnson, new species}

(Figs. 3, 13)

Diagnosis: This new species, and the next one, is assigned to Dipropus Germar as characterized by Candèze (1859), as Ischiodontus Candèze, Schwarz (1906b), and Casari (2013, 2017). It can be recognized apart from described congeneric species by its small size, proportionately long pubescence over a dull coarsely punctured dorsal integument, and the dark infuscate integument, with brown-yellow pronotal and elytral vittae.

Description. Characters of Dipropus Candèze (1859), Schwarz (1906b), and Casari (2013, 2017). Body (Fig. 3) narrowly elongate-oval, moderately convex dorsally; 5.1-6.7 $\mathrm{mm}$ long, $1.6-2.0 \mathrm{~mm}$ wide. Integument dark infuscate, with irregular brown-yellow pronotal vittae surrounding an infuscate subcircular to subcruciate discal macula and lateral margins; elytra with vague to distinct brown-yellow to testaceous discal vittae. Antennae and legs brown. Frontal carina shiny black. Pubescence long, conspicuous, dull golden-yellow.

Head with vertex evenly rounded; frons depressed to shallowly impressed; densely, umbilicately punctured. Frontal margin evenly arcuate, slightly projecting, marginal carina beaded. Antenna long, apex of antennomere 8 reaching apex of pronotal hind angle; antennomere 2 subglobular, antennomere 3 subtriangular; antennomeres $2-5,7$ and 11 length ratio $1.0: 1.7: 3.0: 3.0: 3.3: 5.3$.

Pronotum with lateral margins subparallel in basal half, then tapering anterad, length $0.9 \mathrm{X}$ width, widest across base of hind angles. Hind angles slightly divergent; dorsal carina sharp, short, reaching $0.3 \mathrm{X}$ distance to pronotal anterior margin. Tarsomeres 2 and 3 each with thin ventral membranous lobe; metatarsomere length ratio 1.00:0.54:0.31:0.15:0.77.

Elytra length 1.6X width. Intervals flat to shallowly convex; biserially setose; coarsely punctured, appearing scabrous. Striae shallowly engraved; punctures coarse; apices separately angular.

Aedeagus (Fig.13) with basal piece subquadrate, 0.36X aedeagal length. Median lobe narrow, slightly tapering, then rapidly tapering apically; apex laterally compressed; struts short, straight. Paramere gradually narrowing to preapical lateral spine; narrowly sagittate apically; apex desclerotized, dorsally unisetose, attenuate; ventrally separate, articulate.

Type material. Holotype male; PERU: Madre de Dios, CICRA Fld Stn. garden, $12.56940^{\circ} \mathrm{S} 70.10100^{\circ} \mathrm{W}, 260 \mathrm{~m}$, 9-16.ix.2010, MJ Endara, malaise trap, PER 10-09-MAT-015 / SEMC1098271 (MUSM).

Paratypes: PERU: Madre de Dios, CICRA Fld Stn. garden, $12.56940^{\circ} \mathrm{S} 70.10100^{\circ} \mathrm{W}, 260 \mathrm{~m}, 16-23 . i x .2010$, MJ Endara, malaise trap, PER 10-09-MAT-016 / SEMC1097908 (MUSM), SEMC1097911 (MUSM), SEMC1098060 (MUSM), SEMC1097346 (MUSM), SEMC1097318 (MUSM), SEMC1098193 (MUSM); 25.x-1.xi.2010, PER 10-10MAT-021 / SEMC1097088 (MUSM); 1-8.xi.2010, PER1011-MAT022 / SEMC1097417 (MUSM), SEMC1097515 (MUSM).

Etymology. The species epithet "amarakaeri" is treated as a noun in apposition and is after the Amarakaeri indigenous people and region of Madre de Dios.

Notes. This species is in part the "Anoplischiopsis sp. 1" of Johnson and Chaboo (2015). Casari (2008, 2013)) showed that the genus-level classification within Dicrepidiina requires further study. This new species can be associated with Candèze's (1859) Section II, which is characterized by antennomere 3 being shorter and narrower than antennomere 4 , and differs from Section congeners by its small size, antennomeres 2 and 3 each smaller than antennomere 4 , and opaque integument.

\section{Dipropus losamigos Johnson, new species}

(Figs. 4, 14)

Diagnosis: This new species is assigned to Dipropus Germar as characterized by Candèze (1859), as Ischiodontus Candèze, Schwarz (1906b), and Casari (2013, 2017). It can be recognized apart from described congeneric species by its small size, proportionately long pubescence over a dull coarsely punctured dorsal integument, and the pale brown pronotal and elytral vittae.

Description. Characters of Dipropus Candèze (1859), Schwarz (1906b), and Casari (2013, 2017). Body (Fig. 4) narrowly elongate-oval, moderately convex dorsally; 5.0-5.6 

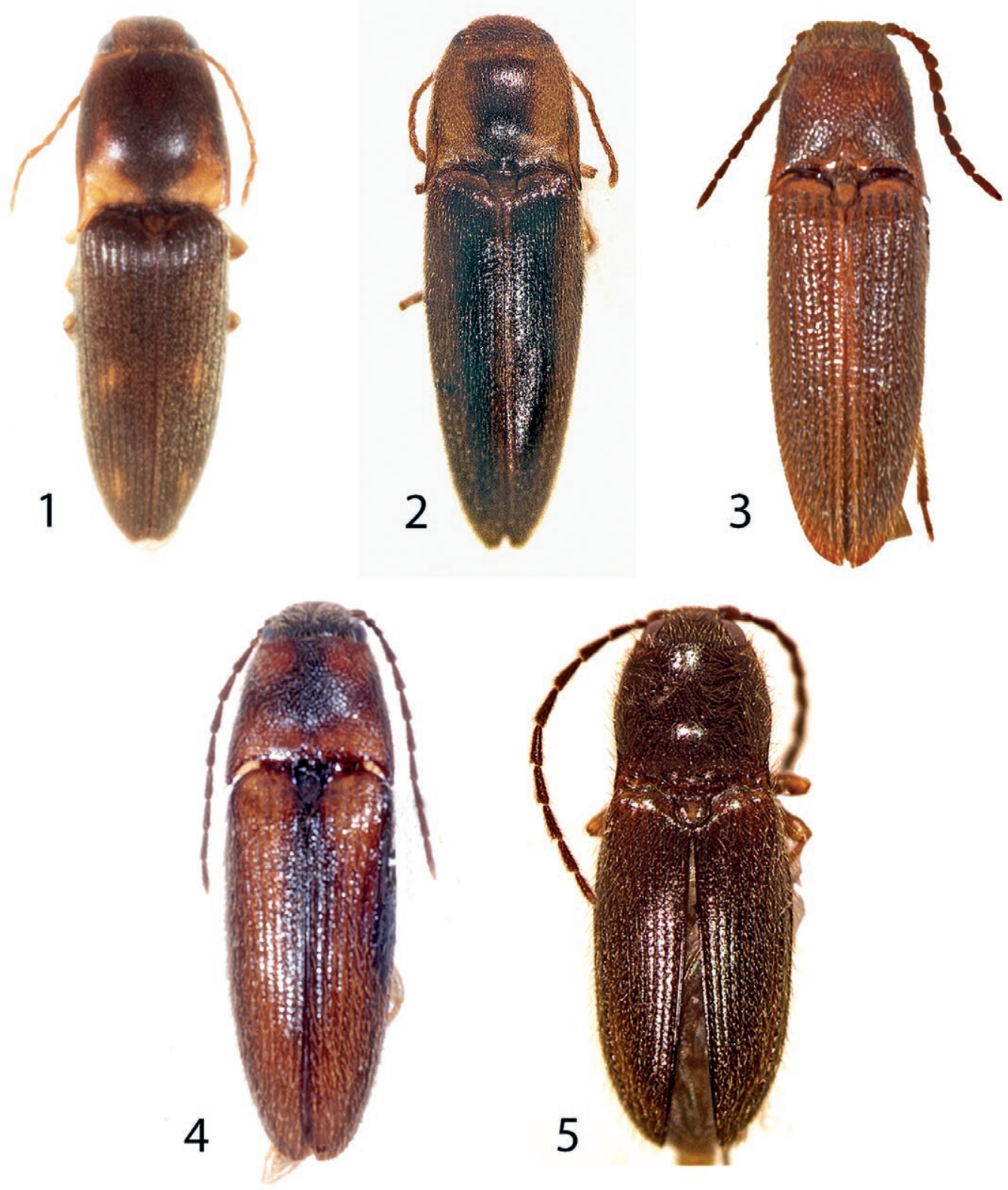

Figures 1 - 5. New Elateridae from Peru, adult habitus. 1) Conoderus wachiperi new species. 2) Cosmesus aca new species. 3) Dipropus amarakaeri new species. 4) Dipropus losamigos new species. 5) Esthesopus machiguenga new species.

mm long, 1.5-1.7 mm wide. Integument dark infuscate, with brown to light brown margins, broad pronotal and elytral vittae, the later merging at suture apically. Antennae brown, legs yellow-brown. Frontal carina shiny black. Pubescence long, conspicuous, dull golden-yellow.

Head evenly rounded, very densely, umbilicately punctured. Frontal margin evenly arcuate, slightly projecting, marginal carina beaded. Antenna long, apex of antennomere 8 reaching apex of pronotal hind angle; antennomere 2 subglobular, antennomere 3 triangular, length subequal to antennomere 2 ; antennomeres 2-11 length ratio $1.0: 1.0: 2.8: 2.8: 2.8: 3.0: 3.0: 3.0: 3.0: 4.0$.

Pronotum trapezoidal, length $0.8 \mathrm{X}$ width, widest across base of hind angles. Hind angles slightly divergent; dorsal carina sharp, short, reaching $0.3 \mathrm{X}$ distance to pronotal anterior margin. Tarsomeres 2 and 3 each with thin ventral membranous lobe; metatarsomere length ratio 1.00:0.29:0.21:0.14:0.36.

Elytra length $2.4 \mathrm{X}$ width. Intervals flat to shallowly convex; triserially setose; scabrous. Striae shallowly engraved; punctures small, setose; apices separately rounded.

Aedeagus (Fig. 14) with basal piece subquadrate, 0.34X aedeagal length. Median lobe narrow, subparallel, rapidly tapering at apex; struts extended, recurved apically. Paramere narrowing to preapical lateral spine; sagittate apically, dorsally unisetose; apex lightly sclerotized, evenly arcuate lateral margin; ventrally separate, articulate.

Female externally similar to male, but slightly smaller, less coarsely punctured, more shining integument.

Type material. Holotype male; PERU: Madre de Dios, CICRA Fld Stn. Exp. Plot, South Transect, $12.55261^{\circ} \mathrm{S}$ 
70.11008 ${ }^{\circ} \mathrm{W}, 295 \mathrm{~m}, 11-13 . v i i .2010$, Chaboo team, ex flight intercept trap, PER 10-07-FIT-006 / SEMC0956114 (MUSM).

Paratypes: PERU: Madre de Dios, CICRA Fld Stn. Exp. Plot, North Transect, $12.55261^{\circ} \mathrm{S} 70.11008^{\circ} \mathrm{W}, 295 \mathrm{~m}, 11-15$. vii.2010, Chaboo team, ex flight intercept trap, PER 10-07FIT-009 / SEMC0954810 (MUSM); Trail 6, $12.56917^{\circ} \mathrm{S}$ $70.10019^{\circ} \mathrm{W}, 250-295 \mathrm{~m}, 10 . v i i .2010$, C.S. Chaboo ex hand coll., PER10-07-CSC-023 / SEMC0954629 (MUSM); CICRA Field Station, garden, $12.56940^{\circ} \mathrm{S} 70.10100^{\circ} \mathrm{W}, 260 \mathrm{~m}$, 22-29.vii.2010, MJ Endara, malaise trap, PER 10-07-MAT008 / SEMC1096788 (MUSM), SEMC1096624 (MUSM), SEMC1096633 (MUSM), SEMC1096620 (SEMC), SEMC1096637 (PJJC); 19-26.viii.2010, PER 10-08-MAT-012 / SEMC1096222 (MUSM).

Etymology. The species epithet "losamigos" is treated as a noun in apposition and comes from the Rio de Los Amigos region of Madre de Dios in which the type locality is located.

Notes. This species is in part the "Anoplischiopsis sp. 1" of Johnson and Chaboo (2015). Casari (2008, 2013) showed that the genus-level classification within Dicrepidiina requires further study. This new species can be associated with Candèze's (1859) Section II, which is characterized by antennomere 3 being shorter and narrower than antennomere 4, and differs from Section congeners by its small size, antennomeres 2 and 3 each smaller than antennomere 4 , and opaque and bicolored dorsal integument.

\section{Esthesopus machiguenga Johnson, new species}

(Figs. 5, 15)

Diagnosis: With the characters of Esthesopus Eschscholtz (Candèze 1860, Schwarz 1907, Becker 1961). It superficially resembles the syntypes of Horistonotus spernendus (Erichson) from Colombia, but tarsomeres 4 have membranous ventral lobes, the antennae are much longer, reaching beyond the body midlength and more slender overall, dorsal setae longer and suberect, elytral striae more finely punctured, intervals shallowly convex and distinctly punctured, and pronotal and elytral bases lighter colored.

Description. Body (Fig. 5) $3.8 \mathrm{~mm}$ long, $1.3 \mathrm{~mm}$ wide. Integument dark brunneo- piceous, yellow-brown margins and highlights on anterior pronotal margin, scutellum, elytral base, hypomeron posterior margin, and legs. Pubescence fine, hair-like, dull yellow.

Head evenly rounded on vertex, frons depressed; finely, sparsely punctate, punctures separated by $1.0-1.5 \mathrm{X}$ own diameter. Frontal carina narrowly reflexed, obtusely subangulate at median, joining eye margin with single ridge. Antenna long, narrowly serrate, apex of antennomere 7 reaching pronotal hind angle apex; antennomeres 2-4 and 11 length ratio 1.0:2.7:3.3, 4.0 .

Pronotum moderately convex, length $0.94 \mathrm{X}$ width; very sparsely, finely punctate, punctures separated by $>1.5 \mathrm{X}$ own diameter. Lateral margins effaced ca. 0.6X distance to anterior margin. Incisures of posterior margin short, obscure. Hind angles with lateral margins subparallel; dorsal carina close to lateral margin; short, ca. $0.47 \mathrm{X}$ distance to anterior margin.
Tarsomere 4 oblique dorsally, lobed ventrally; tarsomere length ratio 1.00:0.59:0.32:0.14:0.36.

Elytral length $2.1 \mathrm{X}$ width, disc depressed. Intervals flat to shallowly convex apically, finely punctured; biseriately setigerous. Striae finely engraved, finely serially punctate; apices conjointly rounded.

Aedeagus (Fig. 15) with median lobe broad basally, rapidly narrow, subparallel at midlength, narrowing to downturned apex. Paramere gradually attenuate from base, sinuate laterally, apices narrowly arcuate and acutely hooked laterally; ventrally separate, articulate.

Type material. Holotype male; PERU: Cusco Dept., Villa Carmen field station, $-1.7 \mathrm{~km}$ west, research transect, $12.89231^{\circ} \mathrm{S}, 71.41930^{\circ} \mathrm{W}, 555 \mathrm{~m}, 22-24 . v .2011$, D.J. Bennett \& E. Razuri, yellow pan trap, PER-11-PTY005 / SEMC01020065 (MUSM).

Etymology. The species epithet "machiguenga" is treated as a noun in apposition and is after the Machiguenga indigenous community in the area of Manu National Park near to the type locality.

Notes. Esthesopus machiguenga keys to E. phisalus Candeze (1860), described from Rio de Janeiro. It differs by being slightly smaller, dark brown integumental coloration with pale highlights at the base, longer antennae, and distribution.

\section{Glyphonyx kosnipata Johnson, new species}

(Figs. 6, 16)

Diagnosis: Characters of Glyphonyx Candèze (1859), Schwarz (1907), and Smith and Balsbaugh (1984). This species is distinguished by the overall yellow-brown integument, the clypeal remnant with a vertical carina, the prosternum with a Y-shaped carina, and morphology of the aedeagus.

Description. Body (Fig. 6) length 3.3-3.4 mm, width 1.1-1.2 $\mathrm{mm}$; elongate, subparallel in dorsal silhouette, shallowly convex dorsally. Integument yellow-brown (testaceous to brunneo-testaceous), with infuscate head variably patterned, semicircular mediobasal area of pronotum, scutellum, and elytral intervals $1-4$ forming a variable pattern from interval 1 only, to a broad triangle reaching to two-third elytral length and a vague area laterally at midlength.

Head with frontal carina arching anterad, forming broad subtruncate juncture with clypeal margin. Antenna short, antennomere 11 exceeding pronotal hind angle apex; antennomeres 2-4 and 11 length ratio 1.0:0.7:1.0, 1.7.

Pronotum wider than long, 0.70 times width (1.44 times wider than long), widest at anterior third, slightly sinuate before hind angles. Dorsal carina of hind angle fine, divergent from lateral margin, reaching two-thirds distance to anterior margin. Prosternum with Y-shaped marginal carinae on posterior process. Metatarsomere length ratio 1.0:0.5:0.4:0.3:0.6; tarsomere 4 membranous anteroventral lobe thin, indistinct when dry; claw with single midlength tooth.

Elytral length 2.6 times width. Striae moderately-coarsely punctured, stria 9 deeply impressed, punctures distinct. Intervals shallowly convex; interval 9 ecarinate apically; apices each with a short acute spine. 

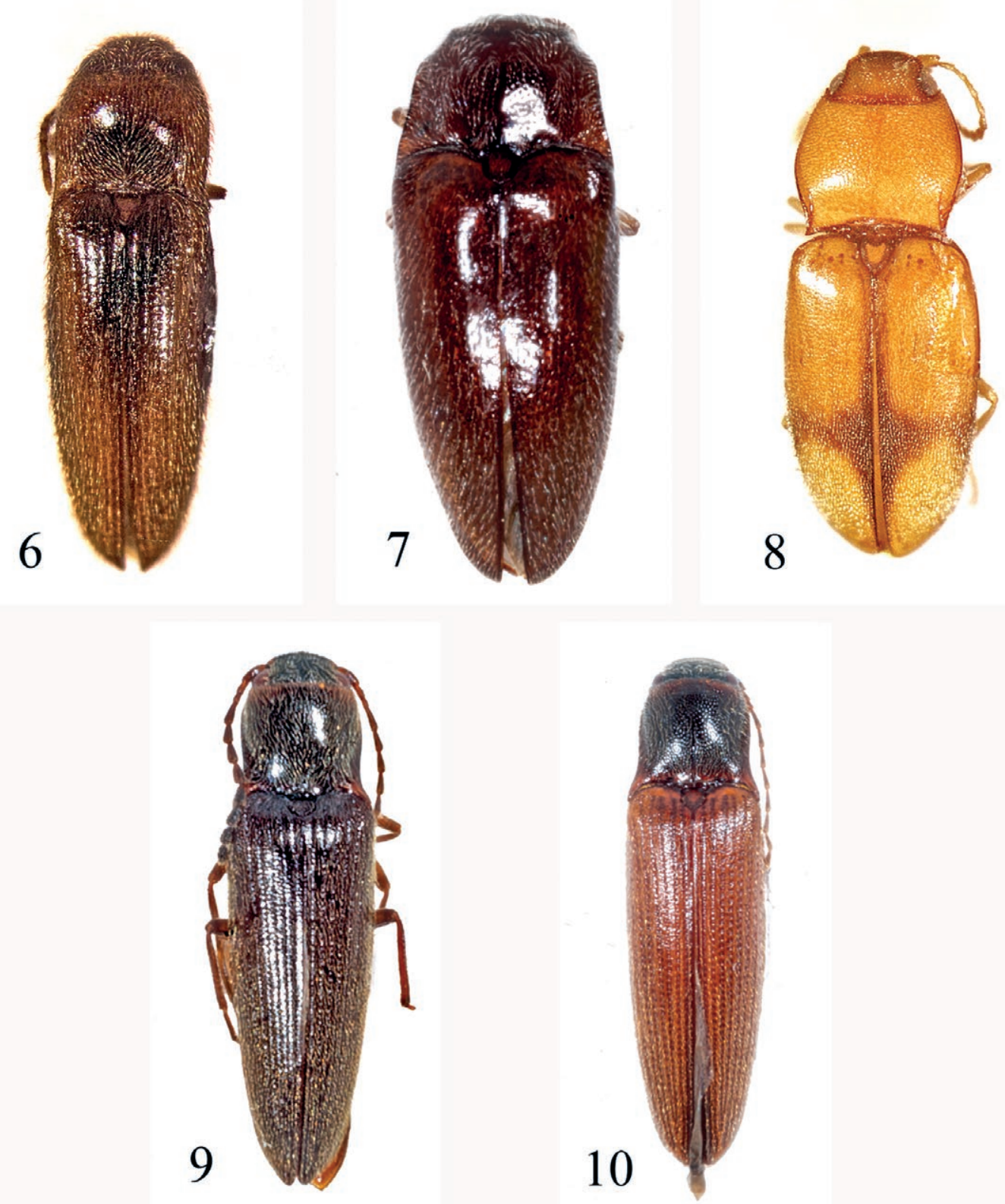

Figures 6 - 10. New Elateridae from Peru, adult habitus. 6) Glyphonyx esaejas new species. 7) Lissomus carmen new species. 8) Paradonus esaejas new species. 9) Pomachilius qusqu new species. 10) Pomachilius wayqecha new species.

Aedeagus (Fig. 16) with attenuate median lobe; paramere subspatulate; ventrally separate, articulate.

Type material. Holotype, male, labeled: PERU, Cusco Dept., Villa Carmen field station, 500 meters east of cafeteria, $12.89459^{\circ} \mathrm{S} 71.39928^{\circ} \mathrm{W}, 504 \mathrm{~m}, 31 . v .2011$, D.J. Bennett, beating branches \& fumigant, PER-11-DJB-049 / SEMC0984145 (MUSM).

Paratypes: same data as holotype: SEMC0984124 (MUSM), SEMC0984128 (MUSM), SEMC0984129 (MUSM), SEMC0984132 (MUSM), SEMC0984139 (MUSM), SEMC0984141 (MUSM), SEMC0984142 (SEMC), SEMC0984157 (SEMC), SEMC0984161 (SEMC), SEMC0984180 (SEMC), SEMC0984186 (PJJC).
Etymology. The species epithet "kosnipata" is treated as a noun in apposition and is in reference to the valley in which the type locality is located.

Notes. The new species is the "Glyphonyx sp. 1" of Johnson and Chaboo (2015). Glyphonyx Candèze (1863) is among the more diverse and poorly studied genera of elaterid beetles in the Americas. Champion (1896) reviewed 24 species for southern North America, of which 18 were described as new species. Smith and Balsbaugh (1984) revised 17 species for the Nearctic Region, with eight described as new species, and synonymized Microglyphonyx Champion.

Four species of Glyphonyx are recorded from South America (Schenkling 1927, Blackwelder 1944): G. antiquus Candèze 
described and recorded from "Nouvelle-Grenade" (= Colombia); G. cruciellus (Erichson) described from Mexico and recorded also from Colombia, Venezuela, Panama, and Guatemala; and $G$. niger Steinheil and G. suturellus Steinheil described from Antioquia and Tolima departments of west-central Colombia.

Glyphonyx kosnipata is the first species of the genus reported south of the equator and provides a new country record for the genus. Champion (1896) noted that his specimens of G. cruciellus from Colombia and Venezuela differed from the Mexican forms, suggesting that he probably confounded two or more species. Based on examinations of the Champion and other Glyphonyx specimens from Panama and Colombia it is doubtful that $G$. cruciellus was correctly reported from South America.

\section{Lissomus carmen Johnson, new species}

(Figs. 7, 17)

Diagnosis: With the characters of Lissomus Dalman, Bonvouloir (1859) and Gerstäcker (1860). This new species and $L$. discedens Bonvouloir differ from most Lissomus species by the subparallel elytral margins and body with long and conspicuous grey pubescence. It differs from $L$. discedens by having retrose spines on the aedeagal median lobe, broadened and apically subtruncate aedeagal paramere, and the pronotal hind angles are shallowly impressed basally and curved downward apically.

Description. Characters of Lissomus (Bonvouloir 1859, Gerstäcker 1860). Body (Fig. 7) length 7.4-8.3 mm, width 3.0-3.4 $\mathrm{mm}$; dorsal silhouette subparallel at midlength, to elongateovoid, tapering posteriorly. Integument shining brunneopiceous to piceous; antennae and legs rufobrunneous. Pubescence pale grey; relatively long, suberect to recurved.

Head with frons shallowly impressed; deeply, moderatelydensely punctured, punctures separated by $\leq 0.5$ times own diameter. Antenna moderately long, antennomere 11 reaching posterior margin of hypomeron; antennomere 2 short, subcylindrical, antennomere 3 short, subserrately widened, antennomeres 4-10 strongly serrate, antennomere 11 elongate-ovate.

Pronotum subtrapezoidal, margin slightly sinuate anterad of hind angle, strongly narrowing in anterior 0.2 of length. Punctation deep, moderately sparse, punctures separated by 0.8-1.1 times own diameter; midline and posterior paramedial areas impunctate. Disc subsulcate along dorsal carina, deplanate to shallowly impressed toward hind angles. Hind angles slightly divergent, recurved apically; dorsal carina strong, slightly divergent from lateral margin, forming a strong lateral bulge at anterior 0.2 of pronotum.

Elytra with striae of serial punctures subequal to interval punctures. Intervals flat. Stria 9 shallowly sulcate from epipleuron midlength to subapical narrowing; obsolescent before subhumeral groove.

Abdominal ventrite 5 densely punctured, tuberculate along apical margins. Aedeagus (Fig. 17) with basal piece 0.6 times total length; median lobe 0.5 times total length, with dorsal midline carinate, midlength with lateral wings up-curved and retrose; paramere 0.6 times total length, gradually broadening and dorsoventrally compressed apically, apex obliquely subtruncate, densely setose dorsally and ventrally; ventrally separate, articulate.
Type material. Holotype male; PERU, Cusco Dept., Villa Carmen field station, $-1.7 \mathrm{~km}$ west cafeteria, research transect, $12.89213^{\circ} \mathrm{S}, 71.41920^{\circ} \mathrm{W}, 547 \mathrm{~m}, 22-24 . v .2011$, D.J. Bennett \& E. Razuri, Malaise trap, PER-11-MAT010 / SEMC1014745 (MUSM).

Paratypes: PERU, Cusco Dept., Villa Carmen Fld Station, $\sim 1.7 \mathrm{~km}$ west, research transect, $12.89233^{\circ} \mathrm{S}, 71.41928^{\circ} \mathrm{W}$, 555m, 26-28.v.2011, D.J. Bennett \& E. Razuri, Malaise trap, PER-11-MAT015 / SEMC0988233 (MUSM); cafeteria, - 1.7 $\mathrm{km}$ west research transect, $12.89250^{\circ} \mathrm{S}, 71.41917^{\circ} \mathrm{W}, 555 \mathrm{~m}$, 28-30.v.2011, D.J. Bennett \& E. Razuri, flight intercept trap, PER-11-FIT-015 / SEMC0987463 (SEMC).

Etymology. The species epithet "carmen" is treated as a noun in apposition and is in recognition of the Villa Carmen Biological Station operated by the Amazon Conservation Association within the Manu Biosphere Reserve where much of the inventory sampling was conducted, and the family that donated the land for conservation.

Notes. This new species will key to L. discedens Bonvouloir in both Bonvouloir (1859) and Gerstäcker (1860), which was described from "Nouvelle-Grenade." It is readily distinguished from most other Lissomus species by the diagnostic characters, but can be confused with $L$. discedens without an examination of the aedeagus.

\section{Paradonus esaejas Johnson, new species}

(Figs. 8, 18)

Diagnosis: This species possesses the salient characters of Paradonus Stibick $(1971,1990)$. It is similar to P. nivalis (Fleutiaux \& Germain) in size, differing in having the integument pale yellow, including the head; reduced elytral maculae; dorsal sculpture finer in diameter and depth, with the pronotal and elytral punctures larger and the interpunctural spaces wider, 1.0-1.3 time their own diameter; the frontal margin finely carinate and lacking a narrow submarginal impression; and the aedeagal parameres shouldered and attenuate, with a long apical seta each (Fig. 18).

Description. Characters of Negastriinae and Paradonus Stibick (1971, 1990). Body (Fig. 8) length 3.1 mm, width 1.1 $\mathrm{mm}$. Pronotum shallowly convex elytral disc subdepressed. Integument flavotestaceous, except legs pale flavous, sclerite margins and carina darkened, and elytral suture and transverse bands at apical third giving a cruciate pattern. Pubescence fine, pale, suberect.

Head with frontal carina bifurcate at eyes. Antennomeres 2-11 length ratio $1.0: 0.9: 1.3: 1.3: 1.3: 1.1: 1.1: 1.1: 1.4$.

Pronotum wider than long, length 0.8 times width (1.3 times wider than long), widest at midlength, lateral margin evenly arcuate. Discal punctures shallow, moderately-dense, separated by 0.5-0.7 times own diameter; interspaces microreticulate. Dorsal carina of hind angle conjoined with lateral margin at apex, shallowly arcuate, reaching one-third of distance to anterior margin; apices acute, divergent. Tarsi slender, filiform; metatarsomere length ratio 1.0:0.7:0.5:0.4:0.8.

Elytral length 1.7 times width; shallowly convex, subdepressed on disc; shallowly, irregularly and finely punctured. 

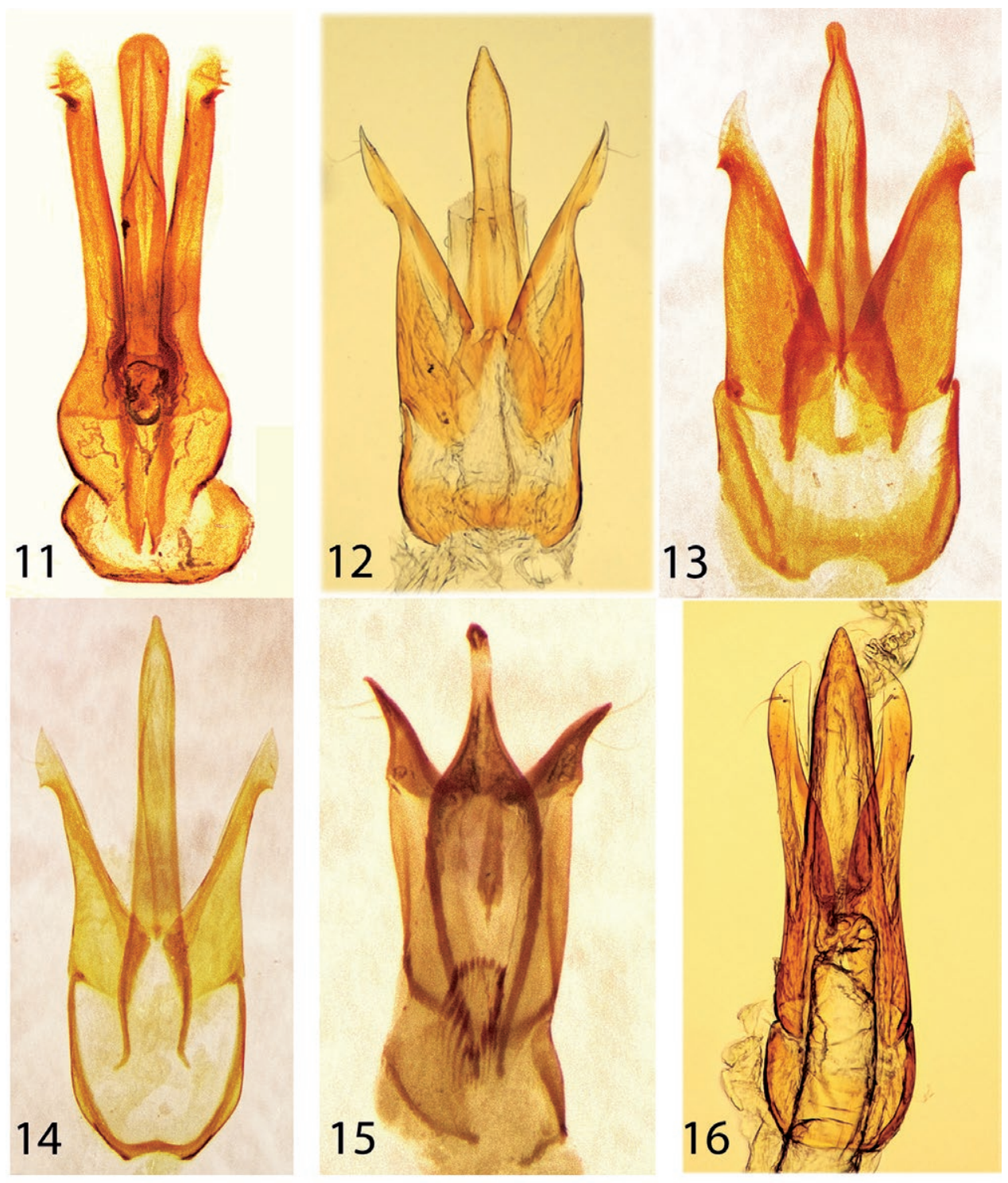

Figures 10 - 16. New Elateridae from Peru, aedeagi. 11) Conoderus wachiperi new species. 12) Cosmesus aca new species. 13) Dipropus amarakaeri new species. 14) Dipropus losamigos new species. 15) Esthesopus machiguenga new species. 16) Glyphonyx kosnipata new species.

Aedeagus (Fig. 18) narrow, median lobe long, attenuate, acute at apex; paramere attenuate, half the length of median lobe, with a long fine subapical seta; ventrally separate, articulate.

Type material. Holotype, male; PERU, Madre de Dios, CICRA Fld Stn. boat launch, $12.57088^{\circ} \mathrm{S} 70.10183^{\circ} \mathrm{W}, 225 \mathrm{~m}$, 14.vii.2010, DJ Bennett, ex sweeping, PER 10-07-DJB029A / SEMC1020914 (MUSM).

Etymology. The species epithet "esaejas" is treated as a noun in apposition and is in honor of the Esa'Ejas indigenous people of the region of origin of the holotype.

Notes. This is the "Paradonus sp. 1" of Johnson and Chaboo (2015). Stibick (1971) established Paradonus for those negastriine click beetles having a characteristic facies with small size, narrowly serrate antennae, broader than long pronotum with arcuate lateral margins, subdepressed to depressed elytral disc, strongly reduced to absent elytral striae, short pronotal hind angles, and filiform tarsi. Champion (1895) revised the Meso- american species and Stibick (1990) revised the eastern Nearctic species. This genus includes some of the smallest known click beetles. Species of Paradonus with known ecological habits are riparian, with both adults and predatory larvae in sandy and sandy-gravelly deposits of both lentic and lotic waters. This new species is expected to be found in similar habitats.

Three described South American species, P. aequalis (Candèze ), $P$. atomus (Candèze), and $P$. oberthuri (Candèze ) remain largely unstudied since their original descriptions (Stibick 1971). Paradonus nivalis is reported from Chile and Argentina, and was illustrated by Solervicens (2014). Paradonus esaejas keys to P. quadrisignatus Champion (1895) from Panama, but differs by the entirely pallid integument and coarser pronotal punctation. The description of $P$. esaejas represents the first species from Peru in the Negastriinae. This is the first report of this subfamily in the Peruvian fauna. 


\section{Pomachilius qusqu Johnson, new species}

(Figs. 9, 19)

Diagnosis: This species possesses the salient characters of Pomachilius Eschscholtz as defined by Candèze (1860) and Schwarz (1906b). It differs from congeners by the combination of the form of the pronotum that is constricted anterad of the hind angles, strongly elevated and sharply carinate hind angle carina; and darker overall coloration with a pale brown band along the pronotal anterior margin, and darkly infuscate antennae and legs, and aedeagal morphology (Fig. 19).

Description. Characters of Pomachilius Eschscholtz (Candèze 1860, Schwarz 1906b). Body (Fig. 9) 8.7 mm long, 2.3 mm wide; elongate, narrow, moderately convex, subparallel at midlength. Integument brunneonigrous (brown-black); antennae and legs brown; elytra, pronotal anterior and posterior margins, hind angles, and antennomere apical angles and venter brunneotestaceous (brown-yellow). Pubescence sparse, setae hair-like, shining yellow.

Head shallowly convex, vaguely longitudinally impressed at median; punctation very dense, punctures separated by $<0.2 \mathrm{X}$ own diameter, umbilicate. Frontal margin narrowly shelf-like, slightly reflexed, carinate; nasale with median carina. Antenna narrowly serrate; moderately long, exceeding pronotal hind angle apex by two segments; antennomeres $2-5+11$ length ratio 1.0:0.8:1.8:1.6, 2.1 .

Pronotum quadrate, length and width equal; punctation moderately dense, punctures ovoid, umbilicate, separated by $\sim 0.5 \mathrm{X}$ own diameter. Hind angles strongly divergent, slightly recurved apically; dorsal carina shallowly arcuate, reaching $0.2 \mathrm{X}$ distance to pronotal anterior margin; deplanate laterad of dorsal carina, margin slightly reflexed, interim area punctate. Tarsus subfiliform; tarsomere 3 oblique at apex, ventrally expanded, densely setose; metatarsomere length ratio 1.00:0.26:0.19:0.14:0.4:0.26.

Elytral length 2.9X width. Intervals flat, triserially setose. Striae of elongate serial punctures with narrow separation giving stitched appearance; apices narrowly truncate, denticulate at sutural and interval 3 angles.

Abdominal ventrite 5 with obtuse denticle at apex. Aedeagus (Fig. 19) with median lobe broad basally,subparallel at midlength apex broadly rounded; paramere gradually narrowing apically, apex broadly membranous, hooked with acute lateral denticle; ventrally separate, articulate.

Type material. Holotype, male; PERU: Cusco Dept., Wayqecha field station, $-1 \mathrm{~km}$ west cafeteria, research plot, $13.17565^{\circ} \mathrm{S} 71.59528^{\circ} \mathrm{W}, 2805$ m, 12-14.v.2011, D.J. Bennett \& E. Razuri, Malaise trap, PER-11-FIT-004 / SEMC0984453 (MUSM).

Paratype: label data same as holotype, PER-11-MAT-001 / SEMC0984319 (MUSM).

Etymology. The species epithet "qusqu" is treated as a noun in apposition and comes from the Aymara name for the old Inca capital and region now known as Cusco.

Notes. This little species keys to $P$. linearis Candèze in his Section II of the genus (Candèze 1860).

\section{Pomachilius wayqecha Johnson, new species}

(Figs. 10, 20)

Diagnosis: This species possesses the salient characters of Pomachilius Eschscholtz as defined by Candèze (1860) and Schwarz (1906b). It differs from congeners by the combination of its small size, generally dark integument with appendages and sclerite highlights brown-yellow to brown, and aedeagal morphology (Fig. 20).

Description. Body (Fig. 10) 6.3-7.1 mm long, 1.5-1.7 $\mathrm{mm}$ wide; elongate, narrow, moderately convex, subparallel at midlength. Integument brunneonigrous (brown-black); antennae and legs brown; pronotal anterior margin, hind angles, antennomere apical angles, elytra, and ventrite lateral margin brunneotestaceous (brown-yellow). Pubescence sparse, setae hair-like, shining yellow.

Head shallowly convex, vaguely longitudinally impressed at median; punctation dense, punctures separated by $<0.3 \mathrm{X}$ own diameter, umbilicate. Frontal margin narrowly shelf-like, slightly reflexed, obtusely carinate, carina shallowly sinuate in anterior view. Antenna narrowly serrate; moderately long, exceeding pronotal hind angle apex by four segments; antennomeres $2-5+11$ length ratio 1.0:0.8:1.8:1.6, 2.0.

Pronotum quadrate, length and width equal; punctation moderately dense, punctures ovoid, subumbilicate, separated by $\sim 0.5 \mathrm{X}$ own diameter. Hind angles strongly divergent, slightly recurved apically; dorsal carina shallowly arcuate, reaching $0.2 \mathrm{X}$ distance to pronotal anterior margin; deplanate laterad of dorsal carina, margin slightly reflexed, interim area impunctate, shining. Tarsus subfiliform; tarsomere 3 oblique at apex, ventrally expanded, densely setose; metatarsomere length ratio 1.00:0.47:0.17:0.07:0.40.

Elytral length 2.9-3.0X width. Intervals flat, triserially setose. Striae of elongate serial punctures with narrow separation giving stitched appearance; apices narrowly truncate, denticulate at sutural and interval 3 angles.

Abdominal ventrite 5 sharply angulate posteriorly. Aedeagus (Fig. 20) with median lobe sides subparallel at midlength, apex broadly rounded; paramere broad along length, dorsoventrally compressed in apical half, apex arcuate and hooked; ventrally separate, articulate.

Type material. Holotype, male; PERU: Cusco Dept., Wayqecha field station, $-1 \mathrm{~km}$ west, research plot, $13.17610^{\circ} \mathrm{S}$ $71.59503^{\circ} \mathrm{W}, 2825$ m, 12-14.v.2011, D.J. Bennett \& E. Razuri, flight intercept trap, PER-11-FIT-004 / SEMC1016731 (MUSM).

Etymology. The species epithet "wayqecha" is treated as a noun in apposition and is after the name of the field station from which the known specimens were collected. The name comes from the Quechua word for brother.

Notes. This species is immediately recognized apart from regional congeners by its rufobrunneous elytra contrasting with the darkly infuscate head and pronotum. 

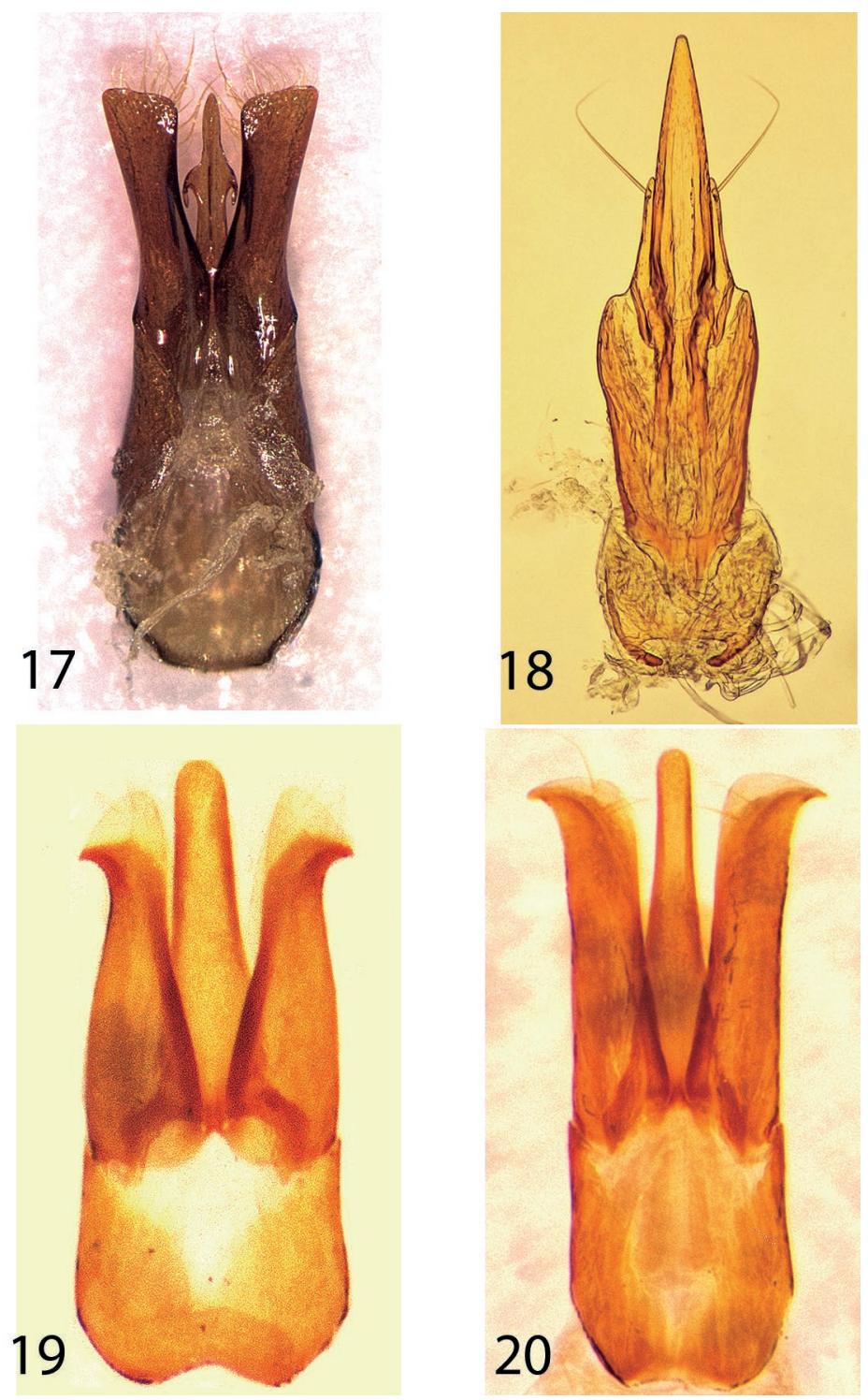

Figures 17 - 20. New Elateridae from Peru, aedeagi. 17) Lissomus carmen new species. 18) Paradonus esaejas new species. 19) Pomachilius qusqu new species. 20) Pomachilius wayqecha new species.

\section{New Taxonomic Combinations}

\section{Conoderus ticuna (Johnson), new combination}

Aeolus livens Candèze 1881: 55, 1891: 78 [not $A$. livens (LeConte 1853: 484)]; Schwarz 1906b: 102; Schenkling 1925: 122; Blackwelder 1944: 290

Aeolus ticuna Johnson 2018: 13 (homonym replacement name)

Specimens examined. PERU: Madre de Dios, CICRA Field Statn, garden

$12.56940^{\circ} \mathrm{S} 70.10100^{\circ} \mathrm{W}, 260 \mathrm{~m}, 11-19 . v i i i .2010$, MJ Endara, malaise trap, PER10-08-MAT-011 / SEMC1095989 (MUSM); 19-26.viii.2010, PER10-08-MAT-012 / SEMC1096149 (SEMC), SEMC1096150 (SEMC); 2-9.ix.2010, PER10-09MAT-014 / SEMC1096862 (MUSM); 16-23.ix.2010, PER1009-MAT-016 / SEMC1097459 (MUSM).

Notes. The specimens documented here provide a new country record for Peru. All specimens examined are female and were compared to the male holotype of $A$. livens from "Ega" (=Tefé), Brazil, and the holotype of $A$. discoidalis Schwarz (1906a) from "Jatahy, Goyaz" (= Jataí, Goiás), Brazil. Probably, A. discoidalis is a synonym of $A$. livens, but additional material from across their combined range needs examination. Both species possess the basic characters of Conoderus Eschscholtz (Johnson 1995), not Aeolus Eschscholtz, particularly with regard to the rounded, non-carinate, anterior angle of the ventral face of the femur of the front legs. Here, A. livens Candèze is transferred as Conoderus livens (Candèze), new combination.

Aeolus livens Candèze became a homonym when Drasterius livens LeConte was listed in Aeolus by Leng (1920). Becker (1961) supported this transfer from Drasterius to Aeolus. It appears that this homonymy was not recognized until Johnson (2018) replaced $A$. livens Candèze with $A$. ticuna. While the latter action was in press the syntypes of $A$. livens Candèze were examined and causing the genus transfer proposed here. The recombination $A$. livens Candèze as $C$. livens removes this overlooked homonymy. 
Conoderus livens is closely related to C. discoidalis (Schwarz), C. fleutiauxi (Candèze), C. partitus (Candèze) and C. sericeus (Candèze). These four species form a distinct species group.

\section{Conoderus platynotus (Candèze), new combination}

Aeolus platynotus Candèze 1859: 284, 1891: 78; Gemminger \& Harold 1869: 1526; Schenkling 1925: 124; Blackwelder 1944: 290 Phedomenus platynotus, of Schwarz 1906b: 92

Specimens examined. PERU: Madre de Dios, CICRA Fld Stn., trail 6, research plot, $12.55207^{\circ} \mathrm{S} 70.10962^{\circ} \mathrm{W}, 295 \mathrm{~m}$, 9-11.vi.2011, Chaboo team, Malaise trap, PER-11-MAT-025 / SEMC1020199 (MUSM); - $2 \mathrm{~km} \mathrm{NW}$ of cafeteria, research plot 12.55237S, 71.10949W, 295m, 11-13.vi.2011, Chaboo team, blue pan trap, PER-11-PTB-011 / SEMC1019365 (MUSM).

Notes. The specimens documented here provide a new country record for Peru. These specimens match the syntypes of this species labelled from Quito, Ecuador (Candèze 1859). This species possesses the combination of characteristics fitting the broadest concept of Conoderus Eschscholtz by Candèze (1859) and Johnson (1995), including the rounded anteroventral angle of the front leg femur, double punctation on the pronotum, and densely punctured hypomeron with a dull sheen. This species is here transferred as Conoderus platynotus (Candèze), new combination, to await further evaluation. Within this large genus $C$. platynotus can be included among the Conoderus varians-group of species. This complex of species was represented by four species in Candèze's (1859) Section III, with a number of species subsequently described.

\section{Probothrium brunnipilis (Candèze), new combination}

Ludius brunnipilis Candèze 1863: 310, 1891: 190; Gemminger \& Harold 1869: 1588; Schenkling 1927: 430

Trichophorus brunnipilis, of Schwarz 1907: 260 (incorrectly listed from Chile)

Crigmus brunnipilis, of Blackwelder 1944: 294

Specimens examined: PERU: Madre de Dios, CICRA Field Stn, garden $12.56940^{\circ} \mathrm{S} 70.10100^{\circ} \mathrm{W}, 260 \mathrm{~m}, 12-19$. vii.2010, MJ Endara, ex Malaise trap, PER 10=08-MAT-011 / SEMC1095986 (MUSM); 26.viii-2.ix.2010, PER 10-08MAT-013 / SEMC1061632 (MUSM); 16-23.ix.2010, PER 10-09-MAT-016 / SEMC1096593 (MUSM), SEMC1097880 (SEMC), SEMC1097325 (SEMC), SEMC1097914 (SEMC), SEMC1097314 (PJJC); 25.x-1.xi.2010, PER 10-1-MAT-021 / SEMC1097087 (MUSM).

Notes. Probothrium brunnipilis, new combination, is a relatively small, $12.5-15.0 \mathrm{~mm}$ long, elaterine click beetle that is dark infuscate to black, with piceous antennae and rufous legs, and a smooth fulvous pubescence. It was described from "Nouvelle-Grenade" and is here reported from Peru as a new country record. This species may be a sister species to the MesoAmerican P. physorhinus Candèze, described from Mexico, with both species appearing similar in appearance and general morphology, including the parallel walls of the mesosternal fossa and the posterior intercoxal portion of the mesosternum strongly declivous, ca. $120^{\circ}$ from longitudinal plane. The intercoxal mesosternal area has a shallowly projecting dome-like form with a median carina, not either an extended horizontal structure (e.g. Orthostethus spp.) or a nearly flat mesosternum with an excavated ovoid intercoxal area (e.g. Diplostethus spp.). Probothrium physorhinus ( $=P$. physorrhinum, of Schenkling 1927: 425; L. physorhinus, of Schenkling 1927: 430) is a revised taxonomic assignment.

The neotropical species presently assigned to Crigmus LeConte, Diplostethus Schwarz, Elater L., Ludius Berthold, Probothrium Candèze, and some of which were formerly assigned to Mulsanteus Gozis or Neotrichophorus Jacobson, require review and reassignment at the genus level.

\section{Additional New Country Records}

\section{Aeolus nigriceps Schwarz}

Aeolus nigriceps Schwarz 1906a: 130, 1906b: 105; Schenkling 1925: 123; Blackwelder 1944: 290; Gaedike 1985: 50

Specimens examined: PERU: Cusco Dept., Villa Carmen field station, near cafeteria, $12.89497^{\circ} \mathrm{S}, 71.40364^{\circ} \mathrm{W}, 520 \mathrm{~m}$, 18.v.2011, D.J. Bennett \& E. Razuri, UV light, PER-11UV-004 / SEMC1019393 (MUSM).

Notes. Originally described from the Departmento de La Paz, Bolivia (Schwarz 1906a). The specimen documented here provides a new country record for Peru.

\section{Anoplischius nigrolaterus Schwarz}

Anoplischius nigrolaterus Schwarz 1904: 55, 1906b: 68; Schenkling 1925: 80; Blackwelder 1944: 298; Gaedike 1985: 51

Specimen examined: PERU: Madre de Dios, CICRA Field Stn, garden $12.56940^{\circ} \mathrm{S} 70.10100^{\circ} \mathrm{W}, 260 \mathrm{~m}, 16-23 . i x .2010, \mathrm{MJ}$ Endara, malaise trap, PER10-09-MAT-016 / SEMC1097501 (MUSM).

Notes. Described from Venezuela (Schwarz 1904), then reported from Argentina by Golbach (1994). The specimen documented here provides a new country record for Peru.

\section{Coctilelater sanguinicollis (Candèze)}

Pyrophorus sanguinicollis Candèze 1878: clxix, 1891: 159; Schwarz 1906: 213; Schenkling 1927: 354; Blackwelder 1944: 286

Coctilelater sanguinicollis, of Costa 1975: 64; Rosa 2007: 146; Chassain \& Touroult 2010: 18

Specimen examined. PERU: Madre de Dios, CICRA Field Stn, garden $12.56940^{\circ} \mathrm{S} 70.10100^{\circ} \mathrm{W}, 260 \mathrm{~m}, 18-25 . x .2010$, MJ Endara, malaise trap, PER10-10-MAT-020 / SEMC1061777 (MUSM).

Notes. Originally described from "Para e Guyane" (Candèze 1878 ) and not since reported from other countries. The specimen documented here provides a new country record for Peru.

\section{Conoderus andicola (Candèze)}

Monocrepidius andicola Candèze 1897: 33; Schwarz 1906b: 96 Conoderus andicola, of Schenkling 1925: 112; Blackwelder 1944: 287

Specimen examined: PERU: Cusco Dept., Villa Carmen field station, 500 meters east of cafeteria, $12.89459^{\circ} \mathrm{S}$, $71.39928^{\circ} \mathrm{W}, 504 \mathrm{~m}, 31 . v .2011$, D.J. Bennett, beating branches \& fumigant, PER-11-DJB0049 / SEMC0984151 (MUSM). 
Notes. Originally described from Bolivia (Candèze 1897). The report of this species from Peru is a new country record

\section{Conoderus partitus (Candèze)}

Monocrepidius partitus Candèze 1859: 254, 1891: 72; Gemminger \& Harold 1869: 1523; Schwarz 1906b: 96

Conoderus partitus, of Schenkling 1925: 117; Blackwelder 1944: 289; Golbach 1994: 35

Specimens examined: PERU: Madre de Dios, CICRA Field Stn, garden $12.56940^{\circ} \mathrm{S} 70.10100^{\circ} \mathrm{W}, 260 \mathrm{~m}, 2-9 . i x .2010$, PER 10-08-MAT-014 / SEMC1096845 (MUSM); 2-11.x.2010, PER10-10-MAT-018 / SEMC1061482 (MUSM).

Notes. Described from "Minas Geraës" [Minas Gerais], Brazil, then subsequently reported from Argentina by Golbach (1994). The specimens documented here provide a new country record for Peru.

\section{Conoderus stigmosus (Germar)}

Monocrepidius stigmosus Germar 1839: 230; Candèze 1859: 218 1891: 70; Gemminger \& Harold 1869: 1524; Schwarz 1906b: 94

Conoderus stigmosus, of Schenkling 1925: 119; Blackwelder 1944: 288; Golbach 1994: 35; Guzmán de Tomé 1995: 122; Correa et al. 2011: 293

Specimen examined: PERU: Madre de Dios, CICRA Fld Stn. trail 10.E7, $12.55860^{\circ} \mathrm{S} 70.09380^{\circ} \mathrm{W}, 255 \mathrm{~m}$, 12.vii.2010, D.J. Bennett, ex hand coll, PER 10-07-DJB-014 / SEMC0985293 (MUSM)

Notes. Originally described from "Brasilia” (Germar 1839), this species has since been additionally reported from Bolivia and Paraguay (Guzmán de Tomé 2005). The specimen documented here provides a new country record for Peru.

\section{Crepidius emarginatus Candèze}

Crepidius emarginatus Candèze 1859: 84, 1891: 60; Gemminger \& Harold 1869: 1514; Champion 1895: 316; Schwarz 1906: 64; Schenkling 1925: 76; Blackwelder 1944: 297; Golbach 1994: 37; Chassain \& Touroult 2010: 24

Specimen examined: PERU: Madre de Dios, CICRA Fld Stn. near cafeteria, $12.56940^{\circ} \mathrm{S} 70.10100^{\circ} \mathrm{W}, 260 \mathrm{~m}, 11 . v i i .2010$, CW Shin ex hand coll, PER 10-07-CWS-011 / SEMC1060978 (MUSM).

Notes. Crepidius emarginatus was described from Brazil and is reported from Nicaragua to Argentina. The specimen documented here provides a new country record for Peru. The species is immediately recognizable apart from congeners by the combination of the hind angles of the pronotum subparallel and black, the elytral apices separately emarginated, and the frons shallowly impressed. The antennae of males are flabellate, with broadly compressed rami, while females have serrate antennae.

\section{Dipropus punctatus (Candèze)}

Ischiodontus punctatus Candèze 1859: 128, 1891: 62; Gemminger \& Harold 1869: 1516; Schwarz 1906b: 79; Schenkling 1925: 91; Blackwelder 1944: 300

Dipropus punctatus, of Arnett 1962: 505; Chassain \& Touroult 2010: 25

Specimens examined: PERU: Cusco Dept., Villa Car- men field station, $-1.7 \mathrm{~km}$ west cafeteria, research transect, $12.89213^{\circ} \mathrm{S}, 71.41920^{\circ} \mathrm{W}, 547 \mathrm{~m}, 22-24 . v .2011$, D.J. Bennett \& E. Razuri, Malaise trap, PER-11-MAT-010/ SEMC1014983 (MUSM); $12.89233^{\circ} \mathrm{S}, 71.41928^{\circ} \mathrm{W}, 555 \mathrm{~m}$, 28-30.v.2011, PER-11-MAT-017 / SEMC1015074; cafeteria $-1.7 \mathrm{~km}$ west, $12.89233^{\circ} \mathrm{S}, 71.41928^{\circ} \mathrm{W}, 555 \mathrm{~m}, 24-$ 26.v.2011, PER-11-MAT-013 / SEMC1014532 (MUSM), SEMC1014495 (SEMC); flight intercept trap, PER-11-FIT-013 / SEMC1017587 (MUSM); Madre de Dios, CICRA Fld Stn., trail 6, research plot, $12.55207^{\circ} \mathrm{S} 70.10962^{\circ} \mathrm{W}, 295 \mathrm{~m}, 11-13$. vii.2010, Chaboo team, ex flight intrcpt trap, PER-11-FIT-017 / SEMC1013631 (MUSM), SEMC1014532 (SEMC); PER11-FIT-021 / SEMC1019318 (MUSM), SEMC1019319 (SEMC), SEMC1019320 (SEMC); 5-7.vi.2011, Chaboo team, Malaise trap, PER-11-MAT-018 / SEMC1019532 (MUSM); 7-9.vi.2011, PER-11-MAT-019 / SEMC1016562 (MUSM); PER-11-MAT-020 / SEMC1015161 (MUSM), SEMC1015162 (SEMC); PER-11-MAT-024 / SEMC1014885 (PJJC); PER-11MAT-025 / SEMC1020197 (MUSM); 11-13.vi.2011, flight intrcpt trap, PER-11-FIT-019 / SEMC0987444 (MUSM); PER-11-FIT-031 / SEMC0987942 (PJJC) .

Notes. Originally described from "Guyane" (Candèze 1859). The specimens documented here provide a new country record for Peru.

\section{Drapetes plagiatus (Boheman)}

Lissomus plagiatus Boheman, 1858: 66 Drapetes plagiatus, of LeConte 1863a: 44

Drapetes praeustus Bonvouloir 1859: 79

[a complete set of references is in Johnson (2015)]

Specimen examined: PERU: Madre de Dios, CICRA Field Station, garden $12.56940^{\circ} \mathrm{S} 70.10100^{\circ} \mathrm{W}, 260 \mathrm{~m}, 1-8$. xi.2010, MJ Endara, malaise trap, PER10-11-MAT-022 / SEMC1097567 (MUSM).

Notes. Distributed from Belize to Brazil, and introduced to Florida (Johnson 2015). The specimen documented here provides a new country record for Peru.

\section{Drapetes unicolor Bonvouloir}

Drapetes unicolor Bonvouloir 1859: 42; Gemminger \& Harold 1869: 1459; Schenkling 1928b: 11; Blackwelder 1944: 304

Specimen examined: PERU: Madre de Dios, CICRA Field Stn, garden $12.56940^{\circ} \mathrm{S} 70.10100^{\circ} \mathrm{W}, 260 \mathrm{~m}, 2-9 . i x .2010, \mathrm{MJ}$ Endara, malaise trap, PER10-09-MAT-014 / SEMC1096888 (MUSM).

Notes. Drapetes unicolor was described from "Sainte-Catherine" [Santa Catarina], Brazil, and is a small parallel-sided member of the brunneus-group of species, that are entirely castaneous. The specimen documented here provides a new country record for Peru.

\section{Esthesopus praeclarus Schwarz}

Esthesopus praeclarus Schwarz 1906a: 148, 1906b: 179; Schenkling 1925: 262; Blackwelder 1944: 303; Gaedike 1985: 55; Golbach 1994: 31

Specimen examined: PERU: Madre de Dios, CICRA 
Field Station, garden $12.56940^{\circ} \mathrm{S} 70.10100^{\circ} \mathrm{W}, 260 \mathrm{~m}, 22-29$. vii.2010, MJ Endara, ex Malaise trap, PER 10-07-MAT-008, SEMC1096593 (MUSM); 2-9.ix.2010, PER 10-09-MAT014, SEMC1096275 (MUSM), SEMC1096280 (SEMC), SEMC1096255 (SEMC); 16-23.ix.2010, PER 10-09-MAT016, SEMC1098179 (MUSM), SEMC1097931 (SEMC), SEMC1098081 (MUSM); 2-11.x.2010, PER 10-10-MAAT018, SEMC1061438 (MUSM), SEMC1061435 (SEMC); 18-25.x.2010, MJ Endara, malaise trap, PER10-10-MAT-020 / SEMC1061905 (MUSM), SEMC1061935 (SEMC); 1-8. xi.2010, PER 10-11-MAT-022, SEMC1097444 (PJJC); 25.x1.xi.2010, PER 10-10-MAT-020, SEMC1097174 (MUSM), SEMC1097190 (PJJC).

Notes. Described from “Jatahy, Goyaz” (= Jataí, Goiás), Brazil and subsequently reported from Argentina by Golbach (1994). The specimens documented here provide a new country record for Peru. Esthesopus praeclarus is the only small, ovoid, red-yellow species of the genus known from Peru.

\section{Horistonotus zonatus Candèze}

Horistonotus zonatus Candèze 1860: 251, 1891: 136; Gemminger \& Harold 1869: 1555; Schwarz 1906b: 178; Schenkling 1925: 259; Blackwelder 1944: 303; Chassain \& Touroult 2010: 25

Specimen examined: PERU: Madre de Dios, CICRA Field Stn, garden, $12.56940^{\circ} \mathrm{S} 70.10100^{\circ} \mathrm{W}, 260 \mathrm{~m}, 16-23 . x .2010, \mathrm{MJ}$ Endara, malaise trap, PER10-09-MAT-016 / SEMC1097903 (MUSM).

Notes. Described from Pará, Brazil. This species is distinctive by a light castaneous integument with an infuscate band across the elytral mid-length. The specimen documented here provides a new country record for Peru.

\section{Neoarhaphes brasiliensis Costa}

Neoarhaphes brasiliensis Costa 1966: 264; Stibick 1971: 389

Specimen examined: PERU: Madre de Dios, CICRA Field Statn, garden $12.56940^{\circ} \mathrm{S} 70.10100^{\circ} \mathrm{W}, 260 \mathrm{~m}, 9-16$. ix.2010, MJ Endara, malaise trap, PER10-09-MAT-015 / SEMC1098126 (MUSM).

Notes. Described from Brazil (Costa 1966) the specimen documented here provides a new country record for Peru.

\section{Pterotarsus histrio Guérin-Méneville}

Pterotarsus histrio Guérin-Méneville 1831: pl. 12, fig. 2, 1843: 194; Dejean 1833: 84, 1836: 93; Latreille 1834: 132; Laporte de Castelanau 1835: 177, 1840: 227; Germar 1839: 193; Brulle \& Blanchard 1846: 147; Drapiez 1853: 230; Lacordaire 1857: 104; Lucas 1857: 69; Gemminger \& Harold 1869: 1486; Girard 1873: 501; Bonvouloir 1875: 847; Horn 1890: 256; Fleutiaux 1896a: 94 , 1896b: 299, 1897: 260, 1899: 248, 1920: 98; Muona 1987: 84; Calder et al. 1993: 1369; Chassain \& Touroult 2010: 21

Pterotartus histrio, of Guérin-Méneville 1844: 36 (genus misspelling) Pterotarsus tuberculatus, of Lucas 1857: 69

Pterotarsus (Lyssothyreus) histrio, Bonvouloir 1875: 847; Bruch 1911: 243

Lissothyreus histrio, of Fleutiaux 1920: 98, 1930: 34; Schenkling 1928a: 7; Blackwelder 1944: 275

Specimen examined, PERU: Madre de Dios, CICRA Fld Stn. Exp. Plot, North Transect, $12.55261^{\circ} \mathrm{S} 70.11008^{\circ} \mathrm{W}, 295 \mathrm{~m}$, 11-13.vii.2010, Chaboo team, ex FIT on Malaise trap, PER 10-07-FIT-007 / SEMC0954441 (MUSM).

Notes. Originally described from "Bresil" (Guérin-Méneville 1829), this highly variable and distinctive species is recorded from lowland and lower montane forest sites from Guatemala to Argentina. The specimen documented here provides a new country record for Peru.

\section{Correction to List of Peruvian Elateridae}

Records of Physorhinus erythrocephalus (Fabricius) in Peru were given by Schaaf (1971). The species was inadvertently absent in the checklist by Johnson and Chaboo (2015), and should be added.

\section{Acknowledgements}

We thank Dr. Diana Silva, Museum of Natural History, University of San Marcos, Lima, and the ACA (Amazon Conservation Association) and their staff at the CICRA (Centro de Investigacíon y Capacitación Rio Los Amigos) for support and assistance. Museum visit hosting, examination of type species permissions, or specimen loans were graciously provided by Bernd Jäger, Museum für Naturkunde, Berlin; Stephan Blank, Senckenberg Deutsche Entomologisches Institut, Müncheberg; Michael Geiser, Max Barclay, and Beulah Garner, Natural History Museum, London; and Natalia Vandenberg and Floyd Shockley, National Museum of Natural History, Washington, D.C. We acknowledge the Peruvian Ministry of Agriculture for issuing the field research permits (to CSC). Fieldwork was funded by National Science Foundation grant EPSCoR 66928 (to CSC) and by a KU Undergraduate Research Award (to HKB). The Ernst Mayr Grants Committee, Museum of Comparative Zoology, Harvard University supported PJJ for a type examination visit to Berlin and Müncheberg, Germany. We are grateful to Drs. Sônia Casari and R. Wills Flowers for their careful and beneficial reviews of the penultimate manuscript draft.

\section{Literature cited}

Aguirre-Tapiero MP \& PJ Johnson 2014. A preliminary checklist, classification, and four new country records for the Elateridae (Coleoptera) of Ecuador. Insecta Mundi 0350: 1-11.

Arnett RH, Jr. 1962. Elateridae Leach, 1815, The Click Beetles. p. 497-512. In: RH Arnett, Jr., 1960-1963. The beetles of the United States (a manual for identification). Catholic University Press; Washington, D.C. xii + 1112 p.

Becker EC 1961. The North American elaterid types of Otto Schwarz, with a revision of Ctenicera bivittata (Melsheimer) and allies (Coleoptera). The Canadian Entomologist 93 (3): 161-181.

Blackwelder RE 1944. Checklist of the coleopterous insects of Mexico, Central America, The West Indies, and South America. United States National Museum Bulletin 185 (Part 2): 189-341. DOI: $10.5479 /$ si.03629236.185.2

Boheman CH 1858. Coleoptera. Species Novas Descripsit, pp. 1-112. Kongliga Svenska Fregatten Eugenies resa omkring Jorden under Befäl af C.A. Virgin Åren 1851-1853. Vetenskapliga Iakttagelser På H.M. Kongung Oscar Des Förstes Befallnning utgifna af Andra Delen. Zoologi. I. Insecta. P.A. Norstedt \& Soner, Stockholm. 617p.

Bonvouloir H. de 1859. Essai monographique sur la Famille des Throscides. A. Deyrolle, Paris. xviii + 144, 5 pl.

Bonvouloir H. de 1875. Monographie de la famille des eucnémides, $4^{\mathrm{e}}$ cahier. Annales de la Sociéte Entomologique de France, ser. 4, 10 (partie supplémentaire): 561-907.

Bruch C. 1911. Catálogo Sistemático de los Coleópteros de La República Argentina. Pars V. Familias Buprestidae, Trixagidae, Monommmidae, Eucnemidae, Elateridae. Revista del Museo de La Plata, 17(segunda serie, 4): 226-260. 
Brullé A. \& É. Blanchard 1846. Insectes. In: A. D’Orbigny, Voyage dans l'Amérique Méridionale (le Brésil, la République Orientale de l'Uruguay, la République Argentine, la Patagonie, la République du Chili, la République de Bolivia, la République du Pérou. Tome sixiéme, $2^{\circ}$ Partie. P. Bertrand, Paris. 222 p. +32 pl.

Calder AA 1996. Click beetles: Genera of Australian Elateridae (Coleoptera).Collingwood, Australia: CSIRO Publishing.

Calder AA, JF Lawrence, \& JWH Trueman. 1993. Austrelater, gen. nov. (Coleoptera: Elateridae), with a description of the larva and comments on elaterid relationships. Invertebrate Taxonomy 7: 1349-1394.

Candèze ECA 1859. Monographie des Élatérides, tome second. Mémoires de la Société royale des sciences de Liège 14: 1-543.

Candèze ECA 1860. Monographie des Élatérides, tome troisième. Mémoires de la Société royale des sciences de Liège 15: 1-512.

Candèze ECA 1863. Monographie des Élatérides, tome quatrième. Mémoires de la Société royale des sciences de Liège 17: 1-534. DOI: 10.5962/bhl.title.47120

Candèze ECA 1878. Élatérides nouveaux. Comptes-Rendus des Séances de la Société Entomologique de Belgique, Annales de la Société Entomologique de Belgique. 20: li-lxi, lxxv-lxxxv, cxxxv-cxliii, clxi-clxxii, clxxxix-cxcix.

Candèze ECA 1881. Elaterides nouveaux (troisieme fascicule). Mémoires de la Société royale des sciences de Liege ser. 2, 9: $1-117$.

Candèze ECA 1891. Catalogue Méthodique des Élatérides connus en 1890. H. Vaillant-Carmanne, Liège. xii + 246 p. DOI: 10.5962/bhl.title.47119

Candèze ECA 1897. Élatérides Nouveaux. Sixième fascicule. Mémoires de la Société royale des sciences de Liège, sér. 2, 29: 3-88.

Casari SA 2008. A phylogenetic study of the subtribe Dicrepidiina (Elateridae, Elaterinae, Ampedini). Revista Brasileira de Entomologia 52(2): 182-260.

Casari SA 2013. New genera of Dicrepidiini from the Neotropical Region (Coleoptera, Elateridae, Elaterinae, Ampedini). Zootaxa 3721(2): 143-156.

Casari SA 2015. New species of Anchastus LeConte, 1853 from South America (Elateridae, Elaterinae, Ampedini, Physorhinina). Zootaxa 3986(1): 1-34.

Casari SA 2017. A new genus and two new species of Dicrepidiina (Coleoptera: Elateridae: Elaterinae: Ampedini) from Brazil, with a revised key to the genera of the subtribe. The Coleopterists Bulletin 71(4): 753-763.

Chaboo CS 2015. Beetles (Coleoptera) of Peru: A survey of the families. Part I. Overview. Journal of the Kansas Entomological Society 88(2): 135-139. DOI: $10.2317 / 0022-8567-88.2 .135$

Chaboo CS \& A. Catenazzi. 2015. Beetles of Peru: Biogeography. Journal of the Kansas Entomological Society 88 (2): 140-143. DOI: $10.2317 /$ kent-88-02-140-143.1

Champion GC 1894-1896. Fam. Elateridae, pp. 258-556, pls. 11-24. In: FD Godman, and O. Salvin, eds., , Biologia CentraliAmericana, Insecta, Coleoptera, vol. 3, part 1, Serricornia. R.H. Porter, London.

Chassain J. and J. Touroult 2010. Les Élatérides de Guyane (Coleoptera, Elateridae), p. 14-30. Contribution à l'étude des Coléoptères de Guyane, Tome II. Bulletin de liaison d'ACOREP-Fance "Le Coléoptèriste", Supplément. 88 p.

Corrêa VA, SA Casari and JR Miras Mermudes 2011. Inventário de Elateridae (Coleoptera) de Vila Dois Rios, Ilha Grande, Angra Dos Reis, Rio de Janeiro. Biota Neotropica 11(4): 291-297.

Costa C. 1966. On a new genus of Hypolithinae (Col., Elateridae). Papéis Avulsos do Departamento de Zoologia, São Paulo 19(23): 261-267.

Costa C. 1975. Systematics and evolution of the tribes Pyrophorini and Heligmini, with description of Campyoxeninae, new subfamily (Coleoptera, Elateridae). Arquivos de Zoologia 26(2): 49-190

Dejean PFMA 1833. Catalogue des Coléoptères de la Collection de M. Le Comte Dejean [2 $2^{\text {nd }}$ edition][Livraisons 1-2]. MéquignonMarvis; Brussels, Belgium. 176 p.
Dejean PFMA 1836. Catalogue des Coléoptères de la Collection de M. Le Comte Dejean. Troisième edition, revue, corrigée et augmentée. [Livraisons 1-4] Méquignon-Marvis; Brussels, Belgium. $384 \mathrm{p}$.

Drapiez PAJ 1853. Ptérotarse. Pterotarsus, p. 230. Dictionnaire classique des sciences naturelles, présentant la definition, l'analyse et l'histoire de tous les êtres qui composent les trois règnes, leur application générale aux arts, à l'agriculture, à la medicine, à l'économie domestique, etc.; résumant les travaux de Buffon, Daubenton, Lacépède, Cuvier, de Jussieu, etc., etc. Tome neuvème. Meline, Cans et $\mathrm{C}^{\mathrm{e}}$, Bruxelles. 704 p.

Erwin TL \& CJ Geraci 2009. Amazonian rainforests and their richness of Coleoptera, a dominant life form in the Critical Zone of the neotropics, pp. 49-67. In: RG Foottit and PH Adler, eds., Insect Biodiversity: Science and Society. WileyBlackwell Publishing, West Sussex, UK. 632 p.

Evenhuis NL 2018. Abbreviations for insect and spider collections of the world. Available at: http://hbs.bishopmuseum.org/ codens/codens-inst.html (Last accessed 5 February 2018).

Fleutiaux E. 1896a. Catalogue des Eucnemidae du Muséum d'Histoire Naturelle de Paris. Bulletin du Museum d'histoire Naturelle 2: 92-94.

Fleutiaux E. 1896b. Collection des Eucnemidae du Muséum d'Histoire Naturelle de Paris. Memoires de la Société Zoologique de France 9: 279-299.

Fleutiaux E. 1897. Liste des Eucnemidae du Musée de Berlin et description des espèces nouvelles. Annales de la Société Entomologique de Belgique 41: 250-261.

Fleutiaux E. 1899. Eucnemidae de la Collectioin Fry. Annales de la Société Entomologique de Belgique 43: 220-249.

Fleutiaux E. 1920. Études sur les Melasidae (Coleoptera-Serricornia). Annales de la Société Entomologique de Belgique 60: 93-104.

Fleutiaux E. 1930. Liste des Melasidae de la Guyane Française et descriptions d'espèces nouvelles. Annales de la Sociéte Entomologique de France, sér. 4, 49: 29-46.

Foottit RG \& PH Adler. 2009. Insect Biodiversity: Science and Society. Wiley-Blackwell Publishing, West Sussex, UK. 632 p.

Gaedike H. 1985. Katalog der in den Sammlungen der Abteilung Taxonomie der Insekten des Institutes für Pflanzenschutzforschung, Bereich Eberswalde (ehemals Deutsches Entomologisches Institut), aufbewarhrten Typen - XXIII (Coleoptera: Rhipiceridae, Cebrionidae, Elateridae, Eucnemidae, Throscidae, Chelonariidae, Buprestidae, Phylloceridae, Dicronychidae, Dasccillidae, Helodidae, Dryopidae, Georyssidae, Heteroceridae, Dermestidae, Byrrhidae). Beiträge zur Entomologie 35(1): 13-96.

Gemminger M. \& E. de Harold. 1869. Catalogus Coleopterorum, hucusque descriptorum synonymicus et systematicus. Tome 5. Buprestidae, Trixagidae, Monommidae, Eucnemidae, Elateriae, Cebrionidae, p. 1347-1608 [+ 5]. Berlin.

Germar EF 1839. Ueber die Elateriden mit häutigen Anhängen der Tarsengleider. Zeitschrift für die Entomologie 1: 197-236.

Gerstäcker A. 1860. Die Arten der Gattung Lissomus Dalm., nach dem Material der königl. entomologischen Sammlung zu Berlin. Linnaea Entomologica, 14: 129-179.

Girard M. 1873. Les Insects - Traité Élémentaire d'Entomologie, comprenant l'histoire des espèces utiles et de leurs produits des espèces nuisibles et des moyens de les détruire l'étude de métamorpjoses et des mœurs les procédés de chasse et de conservation. [tome III] Introduction - Coléoptères. J.-B. Bailliére et Fils, Paris. 840 p.

Golbach R. 1994. Elateridae (Col.) de la Argentina. Historia, Catálogo actualizado hasta 1991 inclusive y Clave de subfamilias y de géneros de Centro y Sudamérica. Opera Lilloana 41, 48 p.

Guérin-Méneville FE 1831. Iconographie du règne animal de G. Cuvier, ou representation d'après nature de l'une des espèces les plus remarquables, et souvent non encore figures, de chaque genre d'animaux. Avec un texte descriptive mis au cournat de la science. Ouvrage pouvant server d'atlas a rous les traits de zoologie. Tome II. Planches des Animaux invertébrés [Insect pls 1-104]. J.B. Bailliére, Paris.

Guérin-Méneville FE 1843. Revue critique de la tribu des eucnémides. Annales de la Sociéte Entomologique de France, ser. 2, 1: 163-199. 
Guérin-Méneville FE 1844. Iconographie du règne animal de G. Cuvier, ou representation d'après nature de l'une des espèces les plus remarquables, et souvent non encore figures, de chaque genre d'animaux. [vol. 7] Insects. J.B. Bailliére, Paris. 576 p. +104 pl.

Guzmán de Tomé ME 2005. Clave de las especies de Conoderus Grupo II (Coleoptera: Elateridae). Revista de la Sociedad Entomológica Argentina 64(3): 119-129.

Horn GH 1890. Fam. Throscidae, pp. 193-209, Tab. 10. In: FD Godman and O. Salvin, eds., Biologia Centrali-Americana, Insecta, Coleoptera, Vol. III, Pt. 1. Serricornia. R.H. Porter; London, U.K. xv + 690 p. +27 pl.

Johnson PJ 1995. A new genus of Conoderini, with new generic classifications for Ctenicera sleeperi Becker and Ctenicera pilatei (Champion), and a new species from Jamaica (Coleoptera: Elateridae). The Coleopterists Bulletin 49(1): 59-71.

Johnson PJ 2015. A new species of Drapetes Megerle (Coleoptera: Elateridae), with taxonomic summaries and a key to the species of northern North America. Insecta Mundi 0445: 1-13.

Johnson PJ 2017. A new species of Dodecacius Schwarz (Coleoptera: Elateridae from Madre de Dios, Peru / Una nueva especie de Dodecacius Schwarz (Coleoptera: Elateridae) de Madre de Dios, Perú. Revista peruana de biologia 24(3): 243-248.

Johnson PJ 2018. New species of Elateridae (Coleoptera) from Sonora, Mexico, with new country and state records, new taxonomic changes and a classificatory checklist. Dugesiana 25(1): 11-31.

Johnson PJ and CS Chaboo 2015. Beetles (Coleoptera) of Peru: A Survey of the Families. Elateridae Leach, 1815. Journal of the Kansas Entomological Society 88(2): 269-272. DOI: 10.2317/ kent-88-02-269-272.1

Johnson PJ \& CS Chaboo 2016. First record of the beetle family Throscidae (Insecta: Coleoptera), a new species of Aulonothroscus Horn, and new species records to the fauna of Peru. Revista Peruana de Biología 23(3): 237-242.

Kricher J. 1997. Introduction to the Andes and tepuis. pp. 218-227. A Neotropical Companion: An introduction to the animals, plants, and ecosystems of the New World Tropics. Princeton University, Princeton 218-227.

Lacordaire T. 1857. Famille XXXIII. Thróscides, pp. 90-94, 564. Histoire Naturelle des Insectes. Genera de Coléoptères ou Exposé Mèthodique et Critique de Tous les Generes Proposés Jusqu'ici dans cet Ordre D'Insectes. Tome Quatrième. Librairie Encyclopédique de Roret, Paris. 579 p.

Lamas G. 1997. Comparing the butterfly faunas of Pakitza and Tambopata, Madre de Dios, Peru, or why is Peru such a mega-diverse country?, pp. 165-168. In: U. Ulrich, ed., Tropical biodiversity and systematics. Proceedings Intern. Symp. Biodiversity \& Systematics in Tropical Ecosystems, Bonn, 1994. Zoologisches Forschungsinstitut und Museum Alexander Koenig.

Laporte de Castelnau FL 1835. Études entomologiques, ou descriptions d'insectes nouveaux et observations sur la synonymie. Revue Entomologique 3: 157-181.

Laporte de Castelnau FL 1840. Insectes, pp. 1-324. In: F. Comte de Castelnau and M. Brullé, Histoire Naturelle des Insectes Coléoptères. Tome premier. P. Duménil, Paris. cxxv+324 p., $24 \mathrm{pl}$.

Larsen TH, F. Escobar \& I. Armbrecht. 2011. Insects of the Tropical Andes: Diversity Patterns, Processes and Global Change, pp. 228-244. In: SKR Herzog, R. Martinez, PM Jørgensen \& $\mathrm{H}$. Tiessen, eds., Climate Change and Biodiversity in the Tropical Andes. Inter-American Institute for Global Change Research (IAI) and Scientific Committee on Problems of the Environment (SCOPE). xii+348 p. (Http://www.iai.int).

Latreille PA 1834. Distribution méthodique et naturelle des genres de diverses tribus d'insectes coléoptères, de la famille des serricornes. Annales de la Sociéte Entomologique de France 3: 113-170.

Laurance WF 1998. A crisis in the making: responses of Amazonian forests to land use and climate change. Trends in Ecology and Evolution 13 (10): 411-415.
Laurance WF, JLC Camargo, RCC Luizão, SG Laurance, SL Primm, EM Bruna, PC Stouffer, GB Williamson, J. BenítezMalvido, HL Vasconcelos, KS Van Houtan, CE Zartman, SA Boyle, RK Didham, A. Andrade, and TE Lovejoy. 2011. The Fate of the Amazonian Forest Fragments: A 32-Year Investigation. Biological Conservation 144(1): 56-67.

Lawrence JF, RG Beutel, RAB Leschen, \& A. Ślipiński. 2010. Glossary of morphological terms, pp. 9-20. In: RAB Leschen, RG Beutel, and J F Lawrence (volume eds.), Coleoptera, Beetles, Volume 2: Morphology and systematics (Elateroidea, Bostrichiformia, Cucujiformia partim). In: NP Kristensen and RG Beutel, eds., Handbook of Zoology, Arthropoda: Insecta. Berlin/New York: Walter de Gruyter.

LeConte JL 1853. Revision of the Elateridae of the United States. Transactions of the American Philosophical Society 10: 405-508.

LeConte JL 1863. List of the Coleoptera of North America, Part I. Smithsonian Miscellaneous Collections 6(140): 1-78.

Leng CW 1920. Catalogue of the Coleoptera of America, north of Mexico. John D. Sherman, Jr., Mount Vernon, NY. 470 p.

Lucas PH 1857. Entomologie. In: F. de Castelnau, Animaux nouveaux ou rares récueillis pendant l'expédition dans les parties centrales de l'Amérique du Sud, de Rio de Janeiro a Lima, et de Lima au Para: execute par ordre du gouvernement Français pendant les années 1843 a 1847, sous la direction du Comte Francis de Castelnau. Septième partie. Zoologie 7, tome 3 (partie1). P. Bertrand, Paris. 204 p. +20 pl.

Muona J. 1987. The generic names of the beetle family Eucnemidae (Coleoptera). Entomologica scandinavica 18: 79-82.

Myers N, RA Mittermeier, CG Mittermeier, GAB da Fonseca \& J. Kent. 2000. Biodiversity hotspots for conservation priorities. Nature 403: 853-858.

Mittermeier RA, RB Mast, CP del Prado, and CG Mittermeier. 2005. Peru, pp. 282-297. In: RA Mittermeier, CG Mittermeier \& P. Robles Gil, and, eds., Megadiversity: Earth's Biologically Wealthiest Nations. CEMEX, Monterrey, Mexico.

Nichols SW, \& RT Schuh. 1989. The Torre-Bueno glossary of entomology. New York, New York: The New York Entomological Society. DOI: $10.1017 / \mathrm{s} 0007485300046022$

Rosa SP 2007. Análise filogenética e revisão taxonômica da tribo Pyrophorini Candeze, 1863 (Coleoptera, Elateridae, Agrypninae). $\mathrm{PhD}$ thesis, Universidade de São Paulo, São Paulo. xii +241 p.

Schenkling S. 1925. Elateridae I. Coleopterorum Catalogus auspiciis et auxilio W. Junk, 11, pars 80: 1-263.

Schenkling S. 1927. Elateridae II. Coleopterorum Catalogus auspiciis et auxilio W. Junk, 11, pars 88: 265-636.

Schenkling S. 1928a. Melasidae. Coleopterorum Catalogus auspiciis et auxilio W. Junk, 11, pars 96: 1-110.

Schenkling S. 1928b. Throscidae. Coleopterorum Catalogus auspiciis et auxilio W. Junk, 11, pars 101: 1-26.

Schwarz O. 1904. Neue Elateriden aus Süd-Amerika. Entomologische Zeitschrift, 1904(Heft 1): 49-80.

Schwarz O. 1906a. Neue Elateriden aus Amerika. Deutsche Entomologische Zeitschrift, 1906(Heft 1): 97-158.

Schwarz O. 1906b-1907. Coleoptera, Fam. Elateridae. Genera Insectorum 46B: 1-224 [1906], 225-370 [1907]. V. Verteneuil $\&$ L. Desmeet, Bruxelles, Belgium.

Smith JW and EU Balsbaugh, Jr. 1984. A taxonomic revision of the Nearctic species of Glyphonyx (Coleoptera: Elateridae) with notes on G. quadraticollis Champion. North Dakota Insects Publications, Schafer-Post Series no. 16, 85 p.

Solervicens Alessandrini J. 2014. Coleópteros de la Reserva Nacional Río Clarillo, en Chile central: taxonomía, biología y biogeografía. Corporacion Nacional Forestal, Santiago, Chile. xiv $+479 \mathrm{p}$.

Stibick JNL 1971. The generic classification of the Negastriinae (Coleoptera: Elateridae). Pacific Insects 13(2): 371-390.

Stibick JNL 1990. North American Negastriinae (Coleoptera, Elateridae): The Negastriinae of the eastern United States and adjacent Canada. Insecta Mundi 4(1-4): 99-131. 